MUÑOZ BENITO, L., «La filiación derivada de técnicas de reproducción asistida», REDUR I4, diciembre 20I6, págs. 2I9256. ISSN i695-078X

\title{
LA FILIACIÓN DERIVADA DE TÉCNICAS DE REPRODUCCIÓN ASISTIDA
}

\author{
Lucía MUÑOZ BENITO \\ GRADUADA EN DERECHO \\ UNIVERSIDAD DE LA RIOJA
}

SUMARIO: I. Introducción. II. Cuestiones generales sobre el derecho de filiación. II.I. Concepto y efectos. II.2. Evolución del Derecho de filiación en nuestro ordenamiento jurídico. II.3. Incidencia de la Constitución de I978 en el Derecho de filiación. II.3.I. Principio de igualdad. II.3.2. Favor filii, deber de asistencia y libre investigación de la paternidad. III. La reproducción asistida. III.I. Consideraciones generales sobre la reproducción asistida. III.2. Polémica en torno a la existencia del derecho a la reproducción. III.3. Derecho a conocer el propio origen. IV. Determinación de la filiación derivada de las técnicas de reproducción asistida. IV.I. Consideraciones previas. IV.2. Determinación extrajudicial. IV.2.I. Matrimonial. IV.2.I.I. Homóloga. IV.2.I.I.I. Intervivos. IV.2.I.I.2. Post mortem. IV.2.I.2. Heteróloga IV.2.I.2.I. Matrimonio heterosexual. IV.2.I.2.2. Matrimonio homosexual: doble maternidad por naturaleza. IV.2.2. No matrimonial. IV.2.2.I. Homóloga. IV.2.2.I.I. Intervivos . IV.2.2.I.2. Post mortem. IV.2.2.2. Heteróloga. IV.2.2.2.I. Con consentimiento del varón no casado. IV.2.2.2.2. Mujer en solitario. IV.3. Gestación por sustitución. IV.4. Determinación judicial: acciones de filiación. IV.4.I. Acciones de filiación en caso de fecundación heteróloga. IV.4.2. Acciones de filiación en caso de fecundación homóloga. V. Conclusiones.

RESUMEN: La filiación es la relación entre unos padres y sus hijos y debe determinarse formalmente para generar efectos jurídicos. La determinación de la filiación de los niños nacidos mediante técnicas de reproducción asistida se regula en la LTRHA bajo unas reglas específicas basadas en principios distintos a los que inspiran el régimen del Código civil. No obstante, la LTRHA se remite a la aplicación del Código civil para salvar todas las reglas que en ella no se contienen, con los problemas jurídicos que este modo de proceder conlleva. El objetivo de este trabajo es el análisis de la determinación de la filiación derivada de técnicas de reproducción asistida tanto en el plano extrajudicial como judicial.

PALABRAS Clave: filiación, determinación, reproducción asistida

ABSTRACT: The filiation is the relationship between parents and their children and must be formally determined to generate legal effects. The determination of the filiation of children born by assisted reproduction techniques is regulated in LTRHA under specific rules based on different principles to those who inspire the Civil Code. However, LTRHA refers the application of the Civil Code to overcome the rules that this Act doesn't contain, with the legal problems that this method entail. The main aim of this work is to analyze the extrajudicial and judicial determination of filiation resulting from assisted reproduction techniques.

KEYWORDS: filiation, determination, assisted reproduction 


\section{Introducción}

«El sistema familiar actual es plural, es decir, que desde el punto de vista constitucional, tienen la consideración de familias aquellos grupos o unidades que constituyen un núcleo de convivencia, independientemente de la forma que se haya utilizado para formarla y del sexo de sus componentes, siempre que se respeten las reglas constitucionales». El concepto tradicional de familia, cuyas raíces provienen del pensamiento romano, basado en el matrimonio, la heterosexualidad, la procreación natural y donde la mujer progenitora era considerada como madre y el marido de aquélla como padre, ha dejado paso a nuevos modelos de familia formados por parejas homosexuales, monoparentales, parejas unidas o no en matrimonio, y donde se ponen en cuestión la concepción tradicional de maternidad y paternidad. Es por ello que el Tribunal Supremo habla de un «sistema familiar plural», que va emergiendo desde hace ya varios años y al que han coadyuvado los avances sociológicos, legislativos y también científicos, como los producidos en el campo de la reproducción asistida y que han permitido que no solo personas con problemas médicos de esterilidad puedan ser padres, sino también parejas homosexuales o incluso mujeres en solitario.

Estas técnicas de reproducción asistida se regulan en la actualidad en la Ley 14/2006, de 26 de mayo, sobre Técnicas de Reproducción Humana Asistida y han recibido muchas críticas desde el punto de vista ético, pero también jurídico. Así, en concreto en el ámbito del Derecho de filiación, la regulación que de la filiación derivada del empleo de estas técnicas hace la Ley sobre Técnicas de Reproducción Humana Asistida se ha ganado muchos detractores esencialmente porque los principios sobre los que se fundamenta la filiación en esta Ley y los principios sobre los que se fundamenta en el Código civil desde la reforma por la Ley II/I98I, de I3 de mayo son diferentes y, para algunos, inconciliables: en la filiación por reproducción asistida se da prevalencia a la voluntad de quien da su consentimiento para ser padre o madre determinando a su favor la filiación, mientras que en el Código civil prima la verdad biológica y la regulación está encaminada a hacer coincidir a los padres jurídicos con los biológicos.

El objetivo de este trabajo es analizar la determinación de la filiación derivada de las técnicas de reproducción asistida desde el punto de vista extrajudicial y judicial. Para ello resulta necesario en primer lugar hacer referencia a la evolución del Derecho de filiación y a los principios constitucionales sobre los que se sustenta para comprender mejor los aspectos controvertidos de la derivada de técnicas de reproducción asistida y, en segundo lugar, hacer alusión a cuestiones generales sobre la regulación de la reproducción asistida.

STS de i2 de mayo de 20 II. 


\section{Cuestiones generales sobre el derecho de filiación}

\section{II.I. Concepto y efectos}

La filiación es el vínculo que se establece entre un hijo y sus padres. Este vínculo, que inicialmente es biológico y, por tanto, consecuencia del hecho natural de la generación, es decir, de haber nacido de unos progenitores, se configura también como un vínculo jurídico existente entre progenitores e hijos pues de él se derivan consecuencias jurídicas una vez la filiación es determinada. No obstante, muchas veces la filiación biológica y la jurídica no coincidirán².

En el plano jurídico, como digo, la determinación del vínculo de filiación hace que se deriven una serie de efectos a los que se refieren los arts. Iog a iı del Código civil (Cc), como son la determinación de los apellidos del nacido y la obligación del padre y la madre de velar por los hijos menores y prestarles alimentos, con independencia de que ostenten o no la patria potestad. Pero, además, la determinación de la filiación también produce efectos en cuanto a los derechos sucesorios (art. 807 Cc. en cuanto a la condición de herederos forzosos de los hijos respecto de sus padres y de éstos respecto de sus hijos, o art. 93I en cuanto a la sucesión ab intestato, siendo los hijos los primeros llamados a suceder), la atribución de la patria potestad (art. I54 y ss. Cc) o la adquisición de la nacionalidad (arts. I7 y ss. Cc).

\section{II.2. Evolución del Derecho de filiación en nuestro ordenamiento jurídico}

La regulación actual de la filiación en el Código civil es consecuencia de la Ley II/I98I, de I3 de mayo, de modificación del Código Civil en materia de filiación, patria potestad y régimen económico del matrimonio, que llevó a cabo la reforma de la entonces vigente redacción original del Código civil de i889. Esta reforma era necesaria ya que con la entrada en vigor de la Constitución (CE) en I978 se consagraron principios constitucionales, a los que me referiré más adelante, que la regulación original del Código civil no respetaba por lo que era prácticamente obligada una adecuación de la regulación de la filiación a la Constitución dada la inconstitucionalidad sobrevenida de aquélla. No obstante iniciaré esta evolución, como no puede ser de otra forma, desde el origen, es decir, desde lo que contemplaba el Código civil de i889.

\footnotetext{
2 Martínez de Aguirre Aldaz: «La relación jurídica de filiación tiene como fundamento la filiación biológica: ante el derecho positivo son padres e hijos, primariamente, quienes lo son biológicamente. No hay, sin embargo, una correspondencia absoluta entre ambas relaciones. Puede ocurrir que la filiación biológica sea desconocida, y que por tanto no exista filiación jurídica (hijo de padres desconocidos); o bien que la filiación jurídica sea atribuida por error a quien biológicamente no es progenitor. También puede crearse conscientemente una relación jurídica de filiación entre quienes se sabe que no están unidos por vínculos biológicos, como ocurre en la adopción», «Capítulo I3. La Filiación» en MARTínez De AguirRE AldAZ, C., (coord.), Curso de Derecho Civil IV. Derecho de Familia, Madrid, Colex, 2013, pág. 302.

También se pronuncia en este sentido BLASCO GASCó: «Con otras palabras, el legislador no desconoce la realidad biológica y, además, generalmente la toma como base para determinar la relación jurídica de filiación; pero la verdad biológica no es, ni ha sido, el único criterio utilizado por el legislador para determinar y atribuir una relación jurídica de este tipo. En ocasiones no es el más importante; otras veces, como sucede en sede de adopción, ni siquiera la toma en consideración o la toma solo circunstancialmente», Instituciones de Derecho civil. Derecho de familia, Valencia, Tirant Lo Blanch, 20I3, pág. I9I.
} 
La redacción original de I889 distinguía en su articulado (arts. I08 a I4I) entre los hijos legítimos e ilegítimos y, dentro de éstos últimos, diferenciaba entre ilegítimos naturales y los demás hijos ilegítimos ${ }^{3}$. En cuanto a los hijos legítimos, eran los nacidos constante matrimonio y gozaban de la plenitud de derechos que les reconocía el art. II4 Cc (a llevar los apellidos del padre y de la madre, a recibir alimentos de sus padres, ascendientes o hermanos, y a la legítima y demás derechos sucesorios). La determinación de la filiación legítima se fundamentaba en la presunción de paternidad del marido, conforme a la cual se presumían hijos suyos los nacidos después de ciento ochenta días a la celebración del matrimonio y antes de los trescientos siguientes a su disolución o separación de los cónyuges. Esta presunción era prácticamente irrefutable ya que contra la misma no se admitía otra prueba que la que venía dada por la imposibilidad física del marido para tener acceso con su mujer en los primeros ciento veinte días de concepción. Se trataba de una paternidad formal por la cual el marido de la madre era siempre el padre legal de los hijos nacidos de aquélla, por mucho que realmente no fuera su padre biológico.

Por lo que respecta a los hijos ilegítimos, se diferenciaba a su vez, como he dicho, entre hijos ilegítimos naturales y los demás hijos ilegítimos, que la doctrina coincide en denominar como no naturales. Los hijos naturales, definidos en el art. II9.2 Cc como «los nacidos, fuera del matrimonio, de padres que al tiempo de la concepción de aquéllos pudieron casarse sin dispensa o con ella» podían ser legitimados por matrimonio de sus padres, equiparándose entonces a los hijos legítimos y disfrutando de los mismos derechos que éstos (art. I22 Cc), o por concesión real, teniendo entonces derecho a llevar el apellido del padre o madre que solicitara la concesión, a recibir alimentos y a la porción hereditaria que le correspondiera (art. I27 Cc). También podían ser reconocidos por sus padres conjuntamente o por uno solo de ellos (art. I29 Cc) gozando desde ese momento de los derechos recogidos en el art. I34 Cc (a llevar el apellido de quien le reconoce, a recibir alimentos del mismo y a heredar).

En cuanto a los hijos ilegítimos no naturales, se diferencian de los naturales en que mientras que éstos, como he dicho, se concebían por personas que aunque no estuvieran casadas podían contraer matrimonio entre sí, aquéllos eran los concebidos por personas que tenían prohibido contraer matrimonio. Así, la doctrina considera que dentro de esta clasificación se incluyen los adulterinos (aquellos cuyos progenitores, o uno de ellos, estaba ya casado), incestuosos (los nacidos de personas que no podían contraer matrimonio por razón de parentesco) y sacrílegos (concebido por una persona quebrantando el voto de castidad). Estos hijos ilegítimos no naturales solo tenían derecho ex art. I39 Cc a exigir alimentos de sus padres con el contenido regulado en el art. I43 Cc, es decir, a los auxilios

\footnotetext{
${ }^{3}$ Esta clasificación recogida en el Código civil de I889 hunde sus raíces en las categorías que ya reconocieron los romanos. Se refiere a esto AlvarAdo CHACón cuando dice: «Durante el desarrollo del presente trabajo de investigación, se constató al revisar el material bibliográfico seleccionado (acudir a las fuentes romanas primarias), que para los romanos las relaciones filiatorias entre padres e hijos estaban muy bien determinadas, existiendo tres categorías de hijos (...): Hijos Legítimos o Justos, Hijos Vulgo Concepti o Espúreos e Hijos Naturales», «La Filiación en el Derecho Romano», Revista de la Facultad de Ciencias Jurídicas y Políticas, núm. 5, 2009 , pág. 67.
} 
necesarios para la subsistencia y a costear la instrucción elemental y la enseñanza de una profesión, arte $u$ oficio.

Por tanto, de esta regulación se desprende una clara discriminación de la filiación condicionada por el hecho del nacimiento constante o no el matrimonio de los progenitores, dando preponderancia a la legítima sobre la ilegítima y confiriendo derechos a los hijos legítimos que eludía para los ilegítimos ${ }^{4}$.

Además, otra de las características de esta regulación era que prohibía, salvo casos muy concretos, la investigación de la paternidad. Así, la Base $5^{\text {a }}$ de la Ley de Bases de ir de mayo de I888 que autorizaba al Gobierno para publicar un Código civil con arreglo a las bases que dicha Ley contenía, disponía lo siguiente: «No se admitirá la investigación de la paternidad sino en los casos de delito o cuando exista escrito del padre en el que conste su voluntad indubitada de reconocer por suyo al hijo, deliberadamente expresada con ese fin, o cuando medie posesión de estado. Se permitirá la investigación de la maternidad, y se autorizará la legitimación bajo sus dos formas de subsiguiente matrimonio y concesión real, limitando ésta a los casos en que medie imposibilidad absoluta de realizar la primera, y reservando a terceros perjudicados el derecho de impugnar, así los reconocimientos como las legitimaciones, cuando resulten realizados fuera de las condiciones de la ley (...)». Una prueba de ello era también el art. I4I Cc que declaraba la inadmisión en juicio de demandas que tuvieran por objeto investigar la paternidad de los hijos ilegítimos que no tuvieran la condición de naturales.

Por tanto, a grandes rasgos, esta regulación originaria de la filiación en el Código civil estaba presidida por dos principios: jerarquía de las filiaciones y prohibición de investigación de la paternidad'.

Como adelantaba al inicio de este apartado, esta regulación originaria del Código civil se vio abocada a desaparecer tras la entrada en vigor de la $C E$, que recogía, en lo que aquí interesa, el principio de igualdad de los hijos ante la ley con independencia de su filiación (arts. I4 y 39.2 CE) y la libre investigación de la paternidad (art. 39.2 CE), a los que me referiré con más detenimiento en el apartado siguiente. Así, por Ley II/I98I, de I3 de mayo se reformó todo el régimen de filiación contenido en el Código civil.

La regulación de la filiación tras dicha reforma seguía estando en los arts. I08 a I4I Cc pero se modificó tanto su estructura como su contenido. Así, se aparta de la diferenciación entre hijos legítimos e ilegítimos y hace una primera distinción entre la filiación adoptiva y la filiación por naturaleza, en la que diferencia a su vez entre la filiación matrimonial (si están los padres casados entre sí) y la filiación no matrimonial (si en los padres no concurre esa condición del matrimonio). Eso sí, y aquí es donde se produce el

\footnotetext{
${ }^{4}$ BARber CÁrCamo: «Como en los demás Códigos europeos decimonónicos, la finalidad evidente de la regulación sobre filiación venía dada por la protección de la familia legítima y la consiguiente negación de derechos patrimoniales y familiares a los hijos nacidos fuera del matrimonio, al amparo de una determinada concepción social y patrimonial de la familia, de origen romano-canónico», La filiación en España: Una visión crítica, Cizur Menor, Thomson Reuters-Aranzadi, 2013, pág. 22.

${ }_{5}^{5}$ Para una mayor explicación acerca de éstos y otros principios que regían dicha regulación vid. BARBER CÁRCAMO, R., ibídem., págs. 23 y 24.
} 
avance principal, tanto la filiación matrimonial como la no matrimonial, y la adoptiva, surten los mismos efectos ${ }^{6}$ (art. Io8 párrafo segundo Cc). Además, diferencia entre los modos de determinación de la filiación matrimonial y no matrimonial, y concluye con los artículos dedicados a las acciones de filiación, reconociendo en el art. I27 Cc (actualmente en el art. 767.2 de la Ley I/2000, de 7 de enero, de Enjuiciamiento Civil (LEC) en iguales términos) la admisión de la investigación de la paternidad y la maternidad.

La regulación tras I98I ha sufrido algunas reformas. Entre ellas, la principal fue la producida por la LEC en cuya disposición derogatoria única $2 . \mathrm{I}^{\circ}$ deroga los arts. I27 a 130 Cc y los arts. I34.2 y I35 Cc, que ahora pasan a estar incluidos en la citada LEC en términos similares y con alguna adición.

Además, el Tribunal Constitucional (TC) por STC 273/2005, de 27 de octubre y STC I38/2005, de 26 de mayo, declaró respectivamente inconstitucionales el primer párrafo del art. 133 Cc y el primer párrafo del art. 136 Cc. Su reforma, sin embargo, no se ha producido hasta la reciente Ley $26 / 2015$, de 28 de julio, de reforma del sistema de protección a la infancia y adolescencia.

Por lo que respecta a la filiación derivada de la utilización de técnicas de reproducción asistida, sobre la que versa principalmente este trabajo, su regulación no se contiene en el Código civil sino que es objeto de regulación aparte actualmente en la Ley I4/2006, de 26 de mayo, sobre Técnicas de Reproducción Humana Asistida (LTRHA), sobre la cual y su precedente legislativo, la Ley 35/1988, de 22 de noviembre, sobre Técnicas de Reproducción Asistida (LTRA), me referiré con más detalle posteriormente.

\section{II.3. Incidencia de la Constitución de I978 en el Derecho de filiación}

Como ya he adelantado, la incidencia que la entrada en vigor de la CE tuvo en nuestro Derecho de filiación fue muy importante debido a que significó el cambio de los principios por los cuales se regía aquél e hizo necesaria una reforma de su régimen ${ }^{7}$. Los artículos que más incidieron en el régimen de la filiación fueron el I4 y el 32, de donde se infieren principios como la igualdad de los hijos ante la ley con independencia de su nacimiento dentro o fuera del matrimonio; el principio de veracidad biológica; el principio de interés superior de los hijos; y el deber de los padres de prestar asistencia a los hijos habidos dentro o fuera del matrimonio.

\section{II.3.I. Principio de igualdad}

La CE consagra en el art. I4 la igualdad de los españoles ante la ley «sin que pueda prevalecer discriminación alguna por razón de nacimiento». A esto se refiere también el art.

\footnotetext{
${ }^{6}$ A estos efectos ya me he referido en el apartado II.I «Concepto y efectos».

${ }^{7}$ BARber CÁRCAMo refiriéndose a la entrada en vigor de la Constitución y su incidencia en el Derecho civil, se pronuncia aludiendo a que la Constitución obligó «al Derecho civil a salir de una especie de letargo dogmático e ideológico» para así «hacerlo realmente servidor de la realidad social en que ha de ser aplicado», e incluye al Derecho de Familia como uno de los sectores del Derecho civil donde, entre otros, se necesitaba con mayor urgencia la reforma; «La Constitución y el Derecho Civil», REDUR, núm. 2, 2004, pág. 4I.
} 
39.2 CE al expresar la igualdad de los hijos ante la ley «con independencia de su filiación». Con ello, por tanto, se determina la igualdad entre los hijos matrimoniales y los no matrimoniales, lo que se plasma en el art. Io8.2 Cc.

El TC en la STC 154/2006, de 22 de mayo dijo que uno de los factores de discriminación que prohíbe el art. I4 CE es el nacimiento, siendo así que «la filiación extramatrimonial reclama igualdad de derechos con la matrimonial, pues ambas determinan el establecimiento de una idéntica relación jurídica entre los progenitores y el hijo» y que, por tanto «la condición extramatrimonial no podría aceptarse como causa de desigualdad de trato dado que sería expresión de una minusvaloración a la que la Constitución quiere poner barrera, pues es notoria la posición de desventaja y, en esencia, de desigualdad sustancial que históricamente han conllevado las relaciones extramatrimoniales frente a las matrimoniales, así como los efectos desfavorables para los hijos nacidos en aquéllas».

Esta igualdad entre los hijos nacidos dentro o fuera del matrimonio se predica en cuanto a los efectos de la filiación, teniendo los mismos tanto la filiación matrimonial como la no matrimonial. No obstante esta no discriminación es compatible con la existencia de reglas diferentes para una y otra filiación en orden a la determinación y en el régimen de las acciones $^{8}$, lo cual ha sido considerado constitucional por el TC. Así, por ejemplo, en cuanto al ejercicio de las acciones de filiación, se planteó una cuestión de inconstitucionalidad acerca de si el art. I33.I Cc, que solo permite reclamar la filiación no matrimonial cuando no medie posesión de estado al hijo o a sus herederos, podía ser contrario, entre otros, al art. I4 CE, ya que la acción de reclamación de la filiación matrimonial si no media posesión de estado le corresponde al padre, a la madre, al hijo y, excepcionalmente a los herederos del último, por lo que el órgano judicial que proponía la cuestión de inconstitucionalidad entendía que con este régimen se permitía una desigualdad de trato ya que no se daban las mismas oportunidades si mediaba o no matrimonio. El TC por STC 237/2005, de 27 de octubre resolvió esta cuestión de inconstitucionalidad (en relación, como digo, con la posible contradicción con el art. I4 CE, pues también se planteó la colisión con los arts. 24 y 39.I y 2) aludiendo a que «lo que hace el Código civil es establecer un sistema para la determinación, prueba, reclamación e impugnación de la filiación que se articula en función del carácter matrimonial o no matrimonial de la filiación y que, en el supuesto concreto que se nos plantea, se traduce en un diferente régimen para la reclamación de la filiación, cuando falte la posesión de estado, según sea aquélla matrimonial o no matrimonial, pues aunque esta diferencia no puede tener consecuencias sobre sus efectos, por determinación constitucional, sí cabe otorgarle relevancia en relación con la forma de determinar la filiación, que es un aspecto previo, y que puede regirse por criterios distintos» y termina diciendo que «queda justificado el distinto trato que el legislador otorga en un supuesto y en otro, sin que, en razón a las consideraciones expuestas, esta diferencia de trato normativa pueda ser tachada de arbitraria, discriminatoria o carente de fundamento»?

\footnotetext{
${ }^{8}$ Martínez De Aguirre AldaZ, C., «Capítulo i3...», cit., pág. 304.

9 Vid. también STC I38/2005, de 26 de mayo donde el TC considera no discriminatoria ni arbitraria la diferenciación normativa en cuanto a la acción de impugnación de la paternidad matrimonial del art. I36 Cc y
} 
II.3.2. Favor filii, deber de asistencia y libre investigación de la paternidad

Del artículo 39 CE se extraen varios principios constitucionales que afectan a la filiación. Entre ellos el principio de protección integral de los hijos, recogido en el art. 39.2, que lleva a atender al favor filii o interés preferente de los hijos y al cuál la doctrina acude habitualmente para justificar o rechazar ciertas interpretaciones legislativas sobre el Derecho de familia y, específicamente, sobre el Derecho de filiación; y el deber de los padres de prestar asistencia de todo orden a sus hijos habidos dentro o fuera del matrimonio, recogido en el apartado 3 del citado art. 39 y plasmado en el art. IIo Cc.

Otro principio recogido en este artículo y que tiene especial importancia debido al cambio que supuso en la regulación anterior de la filiación es el principio de veracidad biológica $^{\mathrm{Io}}$, conforme al cual será padre jurídico quien sea padre biológico. Este principio tiene su fundamento en la libre investigación de la paternidad que proclama el art. 39.2 CE y que tiene que ser posibilitada por ley.

Como consecuencia de la proclamación de la libre investigación de la paternidad, actualmente el art. 767.2 LEC admite la investigación de la paternidad y de la maternidad en los juicios sobre filiación mediante toda clase de pruebas, incluidas las biológicas. Así, en muchos juicios donde se ventilan acciones de filiación se solicita al demandado que se someta a este tipo de pruebas biológicas como por ejemplo una extracción de sangre, a lo que suelen negarse alegando sus derechos fundamentales a la integridad física e intimidad personal (arts. I5 y I8 CE). En este sentido, una consolidada y acertada jurisprudencia constitucional y del Tribunal Supremo (TS) sostiene que la abstención inmotivada del demandado de someterse a las pruebas médicas adecuadas para la investigación de la paternidad, en sí misma considerada, no puede ser valorada o equiparada a una ficta confessio o admisión implícita de la paternidad o de la no paternidad; no obstante, sí se le considera como un indicio de veracidad que puesto en relación con los demás medios probatorios aportados, permite al juez atribuirle el significado correspondiente y declarar la paternidad del demandado obstruccionista o estimar la impugnación de la filiación ${ }^{\text {II }}$.

las acciones de impugnación contempladas en los arts. I38 y I4I Cc pues el legislador establece un dies a quo diferente para el cómputo del plazo de la acción de impugnación de la paternidad atendiendo a las diferentes formas de determinación de la filiación.

${ }^{\text {ro }}$ A él se refiere la STS II77/2008, de 5 de diciembre al expresar que debe prevalecer «la verdad real sobre la meramente formal o presunta, conforme a los principios informadores de la Ley de I3 de mayo de I98I y, por encima de ella, del artículo 39 de la Constitución, que asegura la protección integral de los hijos (...) y que clama, como señalan las Sentencias de 30 de enero de I993, 23 de marzo de 200 y y 27 de mayo de 2004, contra la inexactitud en la determinación de la paternidad que incidiría en la anomalía de atribuir la potestad sobre ellos a quien no es su progenitor. Conforme a tales superiores principios, la filiación se entiende como una condición personal definida, de una parte, por el hecho de ser veraz el hijo, y por otra, por el de ser verdadero progenitor; y solo desde esa concepción de la filiación, y desde la potenciación de los medios jurídicos para determinarla y lograr el acomodo de la realidad formal a la biológica, puede considerarse satisfecha la finalidad protectora del menor y, en suma, el interés también jurídicamente tutelado de la familia (...)».

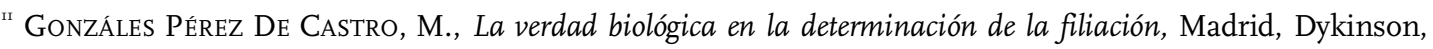
20I3, pág. 46. 
Por otro lado, coincide la doctrina en entender que el principio de veracidad biológica está sometido a límites ${ }^{\mathrm{I} 2}$, entre ellos el que viene dado por el interés preferente del hijo. No obstante, mientras que inicialmente se entendió por parte de la jurisprudencia constitucional que la investigación de la paternidad estaba puesta al servicio de los hijos en defensa de los intereses superiores de los mismos y que debía primar el derecho del hijo a declarar su filiación biológica ${ }^{\text {r3 }}$, el TC modificó su criterio aludiendo a que «la investigación de la paternidad no puede quedar reducida a un derecho del hijo, con exclusión de toda iniciativa por parte de los progenitores, pues también a éstos alcanza un interés en el conocimiento de la verdad biológica ${ }^{\mathrm{T}}$.

Sin embargo, el principio de veracidad biológica y, con él, la libre investigación de la paternidad que consagra la CE no rige cuando se trata de la filiación derivada de técnicas de reproducción asistida. Así, la investigación de la paternidad se ve tremendamente limitada por el anonimato del donante que propugna el art. 5.5 LTRHA, salvo las circunstancias excepcionales en que la identidad del mismo puede ser revelada (cuando haya peligro para la vida o salud del hijo o proceda con arreglo a las leyes procesales penales y siempre que sea indispensable para evitar el peligro o conseguir el fin legal propuesto). No obstante, el anonimato del donante que recogía el art. 5 LTRA (y, actualmente, el art. 5.5 LTRHA, al que me he referido) fue declarado constitucional por la STC I66/I999, de I7 de junio, que consideró que no era incompatible con la libre investigación de la paternidad ya que la CE no recoge en el art. 39.2 «un derecho incondicionado de los ciudadanos que tenga por objeto la averiguación, en todo caso y al margen de la concurrencia de causas justificativas que lo desaconsejen, la identidad de su progenitor» y que el anonimato de donantes «no supone una absoluta imposibilidad de determinar su identidad» ya que se recogen en la ley las circunstancias excepcionales por las que sí podrá revelarse la identidad del donante y también garantiza la ley el derecho a obtener información general de los donantes sin desvelar la identidad.

Por tanto, se aparta la LTRHA del principio de veracidad biológica y adopta como principio que en caso de utilización de técnicas de reproducción asistida heterólogas, es decir, con participación de donante, el hijo no pueda conocer la identidad de su padre biológico ya que éste se ve protegido por el anonimato que consagra la LTRHA y sea, por tanto, imposible, cumplir con el principio de veracidad biológica en la determinación de la filiación.

\footnotetext{
${ }^{12}$ Así, BARber CÁRCAmo se refiere a que la investigación de la paternidad admite su sumisión a límites, haciéndolo compatible con otros principios como el de seguridad jurídica e interés del hijo, La filiación en..., cit., pág. 37.

También GonZÁles PÉREZ De CASTRo dispone que la Constitución instituye un principio de verdad biológica sometido a límites, y que la propia expresión del art. 39 acerca de posibilitar la investigación, significa facilitar, pero no que se exija sin límites, La verdad biológica..., cit., pág. 31.

${ }^{13}$ STC 7/1994, de I7 de enero.

${ }^{14}$ STC 273/2005, de 27 de octubre.
} 


\section{La reproducción asistida}

III.I. Consideraciones generales sobre la reproducción asistida

Desde el nacimiento en Inglaterra en el año I978 de Louise Brown, la primera niña concebida mediante fecundación in vitro, son millones los niños que han nacido como consecuencia de la práctica de ésta y otras técnicas de reproducción asistida en todo el mundo. En España hubo de esperar unos años más para que en I984 naciera el primer bebé concebido mediante fecundación in vitro en Barcelona. Como habitualmente el Derecho no es capaz de avanzar paralelamente a los avances producidos en el campo de la ciencia $^{15}$, no fue hasta I988 cuando se promulgó en España la LTRA, si bien fue una de las primeras en Europa.

La LTRA, fruto del denominado «Informe Palacios» en alusión al Presidente de la Comisión especial creada en el Congreso de los Diputados para el estudio de la fecundación in vitro y de la inseminación artificial y autor del citado Informe que sentaría las bases para la Proposición de Ley que posteriormente acabaría tras el preceptivo iter parlamentario ${ }^{16}$ culminando en la citada Ley, fue objeto de muchas críticas por parte de la doctrina ${ }^{\mathrm{r}}$. El objetivo de la misma era admitir el uso de las técnicas de reproducción asistida ante problemas de esterilidad o en la prevención y tratamiento de enfermedades de origen genético o hereditario (art. I LTRA). No obstante parece que estas finalidades no eran las únicas pues la propia LTRA permitía en su art. 6.I LTRA que las mujeres en solitario acudieran al uso de estas técnicas al expresar que «toda mujer podrá ser receptora o usuaria de las técnicas reguladas en la presente ley», de lo que se entiende que incluso podrían hacerlo sin tener problemas de esterilidad o con fines médicos, sino para satisfacer su deseo de ser madre. Además, la LTRA en su art. 5, como ya he mencionado anteriormente ${ }^{\mathrm{r} 8}$, amparaba el anonimato del donante que donaba sus gametos a la mujer usuaria de las técnicas, permitía investigar y experimentar con gametos y preembriones y, en lo que aquí más interesa, regulaba en sus arts. 7 a io la filiación de los nacidos por medio de estas técnicas.

Estos y otros aspectos de la Ley, que incluía en su articulado materia administrativa, penal y civil, motivaron el recurso de inconstitucionalidad que el Grupo Parlamentario

\footnotetext{
${ }^{15}$ Exposición de motivos LTRA: «Los avances científicos, por otra parte, cursan generalmente por delante del Derecho, que se retrasa en su acomodación a las consecuencias de aquéllos. Este asincronismo entre la ciencia y el Derecho origina un vacío jurídico respecto de problemas concretos, que debe solucionarse (...). Las nuevas técnicas de Reproducción Asistida han sido generadoras de tales vacíos, por sus repercusiones jurídicas de índole administrativa, civil o penal».

${ }^{16}$ Puede consultarse el mismo con detalle en Alkorta Idiakez, I., Regulación Jurídica de la Medicina Reproductiva: Derecho Español y Comparado, Cizur Menor, Thomson-Aranzadi, 2003, págs. I37-I46.

${ }^{\mathrm{r} 7}$ Entre ellos, PANTALEÓN PRIETO, que criticó la misma con expresiones tan duras como: «Por desgracia, en el BOE de 24 de noviembre de 1998 (corrección de errores, BOE de 26 de noviembre) se ha publicado la ley 35/1988, de 22 de noviembre, sobre Técnicas de Reproducción Asistida», «aunque muy mala desde el punto de vista de la técnica jurídica, sea algo mejor que la auténtica obra maestra de torpeza e incompetencia que, desde tal perspectiva, constituía la Proposición de Ley I22/62 (BOC de 9 de mayo de I987) sobre Técnicas de Reproducción Asistida», «como jurista español, me he sentido insultado por la Ley 35/I988», «Contra la Ley sobre Técnicas de Reproducción Asistida», Jueces para la democracia, № 5, I988, págs. I9 y 36.

${ }^{18}$ Vid. Apartado II.3.2. Favor filii, deber de asistencia y libre investigación de la paternidad.
} 
Popular presentó sobre ella. Con base en tres motivos de inconstitucionalidad (contrariar los principios constitucionales que delimitan los rasgos de la institución familiar; vulnerar el art. I5 CE por no definir el status jurídico de los preembriones e incumplir así el deber constitucional que tienen los poderes públicos de establecer un sistema legal para la defensa de la vida; e infringir el art. 8I.I CE por afectar al desarrollo de derechos fundamentales de la persona $y$, sin embargo, no tener carácter orgánico) solicitaban la declaración de inconstitucionalidad de la LTRA en su totalidad o, subsidiariamente, los preceptos específicos que señalaban en su recurso. El recurso fue resuelto por la ya citada STC iı6/ı999, de i7 de junio, que declaró conforme con la Constitución la LTRA.

La LTRA fue modificada en algunos puntos por la Ley 45/2003, de 2I de noviembre $^{\mathrm{r} 9} \mathrm{y}$, finalmente, ambas fueron derogadas por la LTRHA, que en el Derecho comparado en Europa es una de las más permisivas ${ }^{2 \circ}$. Esta Ley, que es la vigente en la actualidad, no varía mucho los planteamientos contenidos en la anterior LTRA. En su exposición de motivos detalla las novedades que introduce, como son: define el concepto de preembrión con efectos circunscritos a su ámbito propio de aplicación; prohíbe la clonación en seres humanos con fines reproductivos; regula las nuevas técnicas de reproducción asistida que pueden practicarse mediante una lista abierta en contraposición a la lista cerrada que enumeraba la LTRA; se extiende el ámbito de actuación al diagnóstico genético preimplantacional que abre nuevas vías en la prevención de enfermedades genéticas; se refuerzan los registros y otros mecanismos de información para contribuir a una mayor información a los usuarios que se sometan a estas técnicas; se eliminan las diferencias en lo que respecta al destino de los preembriones que se encontrasen crioconservados con anterioridad a la entrada en vigor de la Ley 45/2003, de 2I de noviembre, y los que pudieran generarse posteriormente, al igual que se eliminan los límites que se habían establecido en la Ley 45/2003 para la generación de ovocitos.

Con todo, los arts. 7 a Io LTRHA, que son los que regulan la filiación de los nacidos mediante las técnicas de reproducción asistida y sobre cuyo régimen volveré con más detenimiento posteriormente, prácticamente no incorporan modificaciones con respecto a la regulación contenida en los mismos artículos de la LTRA. No obstante, estos artículos sí que han sufrido modificaciones desde entonces: la principal vino dada por la nueva redacción que se dio al art. 7 por la Ley $3 / 2007$, de I5 de marzo, reguladora de la rectificación registral de la mención relativa al sexo de las personas, que añadió un apartado tercero al citado artículo que posibilitaba a la cónyuge de la mujer usuaria de las técnicas de reproducción asistida la determinación a su favor de la filiación respecto del nacido si manifestaba su consentimiento ante el Encargado del Registro Civil antes del nacimiento. Este mismo apartado ha sufrido una modificación por la Ley I9/2015, de I3 de julio, de medidas de reforma administrativa en el ámbito de la Administración de Justicia y del

19 El objetivo de esta Ley 45/2003, según su exposición de motivos, era resolver el problema de la acumulación de preembriones humanos sobrantes, para lo que se modificaron los arts. 4 y II LTRA en aras de «evitar la generación y acumulación de preembriones supernumerarios, a la vez que se intenta reducir la tasa de embarazos múltiples».

${ }^{20}$ Vid. GonZÁles Pérez De CAStro, M., La verdad biológica..., cit., pág. 246. 
Registro Civil suprimiendo la necesidad de que el consentimiento para la determinación de la filiación se produjera con anterioridad al nacimiento. Por último, también por la misma Ley I9/20I5, de I3 de julio se modificaron los arts. 8.2 y 9.3 LTRHA simplemente con motivo de la nueva regulación de la Ley del Registro Civil.

Ahora bien, centrándome ya en la regulación que de la filiación hacen estas leyes, lo cierto es que ni la LTRA ni la LTRHA modificaron el régimen de filiación contenido en el Código civil ni se añadió en él ninguna mención acerca de la filiación derivada de las técnicas de reproducción asistida. No obstante, el art. 7.I LTRHA dispone que «la filiación de los nacidos con las técnicas de reproducción asistida se regulará por las Leyes civiles, a salvo de las especificaciones establecidas en los tres siguientes artículos». Por tanto, la filiación de los nacidos mediante estas técnicas seguirá rigiéndose por lo contenido en el Código civil (y en las leyes autonómicas civiles que tienen su propia regulación como Navarra y Cataluña) pero habrá que tener en cuenta las reglas específicas que se contienen en los arts. 8, 9 у то LTRHA (sin olvidar también la regla del art. 7.3 LTRHA).

Si bien estas Leyes, como he dicho, no modifican el Código civil, conviene subrayar que la LTRHA altera por completo el régimen de filiación contenido en el mismo ya que éste está basado en la verdad biológica y, por consiguiente, en la identificación del padre jurídico como el biológico, mientras que en la filiación derivada de las técnicas de reproducción asistida se da preponderancia a la voluntad de quien desea ser padre, con la consecuencia de que en ocasiones no coincida el padre biológico (quien dona su material genético) con el padre o madre jurídico (que será quien consienta la aplicación de las técnicas en su cónyuge o pareja o la mujer que consiente en que se determine a su favor la filiación del hijo de su cónyuge). Tradicionalmente la filiación derivada de las técnicas de reproducción asistida se ha considerado como incluida en la filiación por naturaleza ya que tiene una base biológica, pero lo cierto es que las normas pensadas para la determinación de la filiación por naturaleza, cuyo fundamento es la verdad biológica, no acaban de encajar en un sistema en el que la procreación no tiene origen en la reproducción sexual y la filiación se determina por la voluntad, como es el derivado del recurso a las técnicas de reproducción asistida ${ }^{2 \mathrm{~T}}$. Lo mismo ocurrirá con el régimen de acciones de filiación, pensadas en el Código civil para poner de manifiesto un vínculo biológico.

Las técnicas de reproducción asistida pueden ser utilizadas en la actualidad tanto por parejas heterosexuales casadas o no que acudan a ellas por problemas de esterilidad así como por parejas homosexuales o incluso por una mujer en solitario. Que el uso de las técnicas de reproducción asistida no se contemple únicamente como una posibilidad de dar a luz a un hijo cuando la vía natural es imposible por problemas de esterilidad sino que pueda voluntariamente acudirse al uso de las mismas para tener descendencia ha llevado a argumentar que el uso de estas técnicas está fundamentado en un hipotético derecho a procrear, sobre el que ahora paso a referirme.

\footnotetext{
${ }^{21}$ FARnós Amorós, E., «La filiación derivada de reproducción asistida: voluntad y biología», Anuario de Derecho Civil, núm. LXVIII-I, enero 20I5, pág. 8.
} 


\section{III.2. Polémica en torno a la existencia del derecho a la reproducción}

El debate sobre si existe o no un derecho a la reproducción o, como muchos autores denominan, derecho a procrear, surge cuando gracias a los avances científicos y tecnológicos comienzan a utilizarse las técnicas de reproducción humana asistida ${ }^{22}$. Así, la doctrina ha buscado desde la promulgación de la LTRA un derecho que fundamente el uso de las técnicas de reproducción asistida, entendiendo parte de la misma que el uso de estas técnicas se basa en el derecho a la salud ${ }^{23}$, mientras que otras voces opinan que el uso de las técnicas de reproducción asistida tiene su fundamento en el derecho a procrear. Obviando ahora hacer referencia a los que consideran que el uso de estas técnicas se basa en el derecho a la salud, me centraré en recoger las opiniones doctrinales que abogan, o no, por la existencia del derecho a procrear.

Debemos partir de que nuestra Constitución no recoge expresamente el derecho a reproducirse, a tener hijos. Por este motivo, quien respalda la existencia del mismo lo entiende como una manifestación de otros derechos que ya están formulados. Así, parte de la doctrina entiende que el derecho a reproducirse puede tener fundamento constitucional en el reconocimiento de la libertad personal que la CE hace en su art. I7.I, pero con límites, debiendo ceder ante otros principios y valores constitucionales ${ }^{24}$.

Otros autores encuadran el derecho a procrear dentro del derecho a fundar una familia, reconocido en nuestro ordenamiento en la medida en que las normas relativas a los derechos fundamentales recogidos en la CE se deben interpretar de conformidad con la Declaración Universal de Derechos Humanos y los Tratados y esta Declaración sostiene que tanto los hombres como las mujeres tienen derecho a fundar una familia. También se ha

\footnotetext{
${ }^{22}$ Ya en el preámbulo de la LTRA se hacía mención a este derecho a procrear y a si realmente existía: «En esta Ley se hace referencia a dos previsibles aplicaciones de estas técnicas de Reproducción Asistida, en nuestra Nación: la gestación de sustitución y la gestación en la mujer sola; posibilidades que llevan a interrogar si existe un derecho a la procreación; si este derecho es absoluto y debe satisfacerse por encima de conflictos entre las partes consideradas insalvables, de extracción ética, o porque chocan contra el bien común que el Estado debe proteger; o finalmente, en el caso de la gestación de sustitución, si las partes pueden disponer libremente en los negocios jurídicos del Derecho de Familia, aun en el supuesto de un contrato o acuerdo previo entre ellas. Son sin duda dos aplicaciones de las técnicas de Reproducción Asistida en las que las divergencias de opinión serán más marcadas, y cuya valoración jurídica resulta dificultosa, no solo en nuestra Nación, como lo aprueban las informaciones foráneas».

${ }^{23}$ Entiende esta parte de la doctrina que la LTRA daba a entender en su art. I que el uso de estas técnicas solo podría realizarse como un método contra la esterilidad o como un tratamiento contra enfermedades, por lo que ubican el empleo de estas técnicas en el derecho a la salud contenido en el art. 43.I CE. No obstante, parece que esta opción no es válida ya que es obvio que las técnicas de reproducción asistida no se utilizan actualmente solo como un método terapéutico. Por ejemplo vid. RoCA TRÍAS, E., «Filiación asistida y protección de derechos fundamentales», DS: Derecho y Salud, Vol. 7, núm.I, I999, págs. 3 y 4.

${ }^{24}$ Así se refiere GómEZ SÁNCHEZ: «el derecho a la reproducción humana encuentra cobijo en esta interpretación de la libertad como derecho-autonomía y muestra tanto una vertiente positiva que permite al sujeto decidir libremente sobre su propia reproducción como una vertiente negativa, que protege igualmente su decisión de no reproducirse. De lo señalado cabe deducir que el derecho a la reproducción forma parte del contenido del derecho a la libertad, como una manifestación directa de la autonomía física de la persona, lo que permite al sujeto acceder tanto a la reproducción natural como valerse de las nuevas tecnologías reproductivas, pero, como el resto de los derechos de nuestro sistema constitucional, no es ilimitado», «El derecho a la reproducción humana: fundamento y nuevos problemas», Perspectivas del Derecho de familia en el siglo XXI, XIII Congreso Internacional de Derecho de Familia. Sevilla y Huelva, del I8 al 22 de octubre de 2004, 2004, pág. I68.
} 
planteado por parte de la doctrina el encuadramiento del derecho a procrear dentro del derecho a una planificación familiar, es decir, a que las personas decidan libremente el número de hijos y cuándo quieren tenerlos encuadrando dicha manifestación dentro del derecho a la intimidad personal y familiar ${ }^{25}$.

Además, ya en el preámbulo de la LTRA parece que se daba vía libre al uso de las técnicas de reproducción asistida no solo para usos médicos ante la esterilidad o como tratamiento de enfermedades (que era, no obstante, a lo que se refería su art.I) sino también como una forma de satisfacer el simple deseo de tener hijos. Así, en el apartado III del preámbulo la LTRA disponía que «desde el respeto a los derechos de la mujer a fundar su propia familia en los términos que establecen los acuerdos y pactos internacionales garantes de la igualdad de la mujer, la Ley debe eliminar cualquier límite que socave su voluntad de procrear y constituir la forma de familia que considere libre y responsablemente», por lo que, como digo, parece que indirectamente se hacía referencia a un derecho a procrear de la mujer. En este sentido puede llegar a afirmarse que las técnicas de reproducción asistida ya han dejado de servir como un simple remedio para la esterilidad y han pasado, además, a servir a los intereses de la mujer que quiere tener hijos y no tiene ningún inconveniente médico para ello ${ }^{26}$.

Quizás la aportación doctrinal más importante en este campo viene dada por ALKORTA IDIAKEZ, que sostiene que el derecho a procrear está emergiendo en el ámbito internacional y lo fundamenta mediante un análisis de los textos internacionales ${ }^{27}$. Además la autora entiende que el conflicto que pueda generar el reconocimiento de este derecho (que llevaría a la mujer a decidir libremente el tener hijos) con los intereses del otro miembro de la pareja deberá ser resuelto ponderando los derechos que asisten a cada una de las partes; es decir, tampoco sería un derecho absoluto y debería tenerse en cuenta el derecho del varón a no ser padre en contra de su voluntad, como hace el Tribunal Europeo de Derechos Humanos en el Caso Evans contra Reino Unido.

\footnotetext{
${ }^{25}$ Recoge estas opiniones doctrinales SERnA MERoÑo, no obstante ella se decanta por encuadrar el derecho a procrear como una manifestación del libre desarrollo de la personalidad que recoge nuestra CE en el art. IO.I como fundamento del orden político y de la paz social, «Las técnicas de reproducción humana asistida: limitaciones para su práctica», Derecho Privado y Constitución, núm. 26, enero-diciembre 20I2, págs. 282-284.

${ }^{26}$ TAmayo Haya: «La ley española ha dejado de ser un remedio para la esterilidad para convertirse en expresión de la defensa de los intereses de la madre hasta el punto de configurar un nuevo derecho subjetivo: el derecho de la mujer a la reproducción (sola, casada, homóloga, heteróloga, post-mortem, homosexual, de una madre casada con otra de la que recibe los óvulos, la inseminación de las dos mujeres con semen del mismo donante)», «Hacia un nuevo modelo de filiación basado en la voluntad de las sociedades contemporáneas», Revista Digital Facultad de Derecho, núm. 6, 2013, págs. 270 y 271.

${ }^{27}$ Según esta autora el derecho a procrear podía fundarse en el derecho a fundar una familia reconocido por la Convención Europea de Derechos Humanos o el Pacto Internacional de Derechos Civiles y Políticos; también en el derecho a la salud reproductiva surgido a raíz de las Conferencias Mundiales de la ONU sobre población y sobre género, donde se acuñó un nuevo principio conocido como «libertad reproductiva», que comprendía el derecho humano básico a decidir libre y responsablemente el número y espaciamiento de los hijos; y también hace referencia al derecho a la autodeterminación reproductiva, recogido en la Convención de la ONU sobre la eliminación de todas las formas de discriminación contra la mujer de i979 y que, aunque tiene un sentido más restringido que el de salud reproductiva, es un derecho humano vinculante y de perfiles bien definidos, «Nuevos límites del derecho a procrear», Derecho Privado Y Constitución, núm.20, enero-diciembre 2006, págs. II-28.
} 
Por el contrario también hay voces que consideran que este derecho a procrear no existe ni puede derivarse de ningún derecho constitucional. Esta parte de la doctrina pone el énfasis en la necesidad de atender a otros intereses más importantes que el derecho de una mujer a ser madre, sobre todo al interés superior de los hijos, y en la no consideración de éstos como un objeto de derecho, así como en la preferencia de que un hijo nazca con el referente de un padre y una madre ${ }^{28}$.

\section{III.3. Derecho a conocer el propio origen}

Habiendo puesto de manifiesto las dudas doctrinales que hay en torno a la existencia o no del derecho a reproducirse cabe ahora hacer igualmente una breve mención a otro derecho como es el derecho a conocer el propio origen o el derecho de un hijo a conocer quiénes son sus padres biológicos y ver cómo la doctrina ha afirmado la existencia o no del mismo. Este derecho, que inicialmente se había suscitado en relación con la adopción $^{29}$, ha pasado a estar presente también cuando se hace uso de las técnicas de reproducción asistida y especialmente en caso de reproducción asistida heteróloga, pues será en este supuesto cuando los padres biológicos no coincidan con los padres jurídicos. Es entonces cuando surge la polémica acerca de si existe o no el derecho a conocer el propio origen, pues el hijo nacido como consecuencia del uso de estas técnicas puede sentir la necesidad de conocer su verdadero origen ya que sus padres jurídicos serán los que hayan prestado el consentimiento al uso de las técnicas y no, como digo, quien haya aportado el material genético.

No ha sido minoritaria la doctrina ${ }^{30}$ que ha escrito acerca de la existencia de este derecho y la ha puesto en relación con la posible colisión con otros derechos fundamentales

\footnotetext{
${ }^{28}$ Niega la existencia del derecho a reproducirse DE VERDA Y BEAMONTE, que entiende que «el interés de una mujer de ser madre mediante el recurso a las técnicas de reproducción asistida debe ceder ante el interés superior del hijo a tener un padre y una madre», «Libertad de procreación y libertad de investigación (algunas reflexiones a propósito de las recientes leyes francesa e italiana sobre reproducción asistida)», Diario La Ley, 2005, pág. 3 versión digital.
}

También LASARTE ÁLVAREZ, que acerca de que una mujer pueda individualmente recurrir a las técnicas de reproducción asistida, crítica que el legislador entienda que «la mujer cuenta con derechos que legitiman el nacimiento de «una familia sin padre» mediante el recurso a las técnicas de reproducción asistida, dejándose inseminar con material reproductor procedente de cualquier banco de órganos», Derecho de familia. Principios de Derecho Civil VI, Madrid, Marcial Pons, 20II, pág. 326.

En el mismo sentido que éste último, criticando que una mujer sola pueda acudir al uso de estas técnicas se refiere DíEZ SoTo a que «tal planteamiento, sustentado en un pretendido «derecho a la procreación» carente de fundamento constitucional, resulta difícilmente conciliable con las exigencias constitucionales», «Comentario jurídico al art.6 LTRHA» en Lledó YAGÜE, F. (Dir.), Comentarios científico-jurídicos a la Ley sobre Técnicas de reproducción humana asistida, Madrid, Dykinson, 2007, pág. 107.

Por su parte, GonzÁles PÉREz De CASTRo sostiene con firmeza que la LTRHA «se basa en un supuesto «derecho fundamental a la procreación», derecho a tener un hijo; que no existe. El hijo nunca puede ser objeto de un derecho subjetivo», La verdad biológica..., cit., pág. 247.

${ }^{29}$ El Código Civil en su art. I80.6 dispone actualmente: «Las personas adoptadas, alcanzada la mayoría de edad o durante su minoría a través de sus representantes legales, tendrán derecho a conocer los datos sobre sus orígenes biológicos».

${ }^{30}$ Entre ellos, una aportación muy reciente sobre este tema: ORDÁs AlONSO, M., «El derecho a la identidad genética versus el anonimato del donante en la procreación mediante técnicas de reproducción asistida», Aranzadi civil-mercantil. Revista doctrinal, núm.I, 20I6, págs. 43-I00. 
y también con el anonimato del donante recogido en el art. 5.5 LTRHA (y, anteriormente, en el art. 5 LTRA).

Así, la doctrina mayoritaria aboga por la existencia de este derecho con fundamento en la dignidad de la persona y en el derecho a la intimidad que recoge la CE en sus arts. Io y I $8^{3 \mathrm{I}}$. Además, el derecho a conocer el propio origen contribuye al libre desarrollo de la personalidad e incluso hay quien sostiene que puede ser elevado a la categoría de derecho de la personalidad $\mathrm{d}^{32}$. Por otro lado, también hay parte de la doctrina que entiende que dicho derecho puede sustentarse en la libre investigación de la paternidad que recoge el art. 39.2 CE y que debería permitir a un hijo conocer cuáles son sus orígenes biológicos ${ }^{33}$.

No obstante el derecho a conocer el propio origen en caso de fecundación asistida con contribución de donante se ve sometido a límites que vienen dados, sobre todo, por el derecho a la intimidad del donante que quiere permanecer en el anonimato; pero también por el derecho a la intimidad personal y familiar de los padres jurídicos del hijo en el sentido de la afectación que para la convivencia familiar y la intimidad de los padres puede suponer que el hijo conozca la forma en que se ha engendrado ${ }^{34}$; y también debe verse limitado porque la filiación ya está determinada a favor de los padres jurídicos ${ }^{35}$.

Al hilo de las voces que consideran que el anonimato del donante del art.5.5 LTRHA es contrario al derecho a conocer el propio origen, puede entenderse ya solucionado este aspecto con la citada STC I66/1999, de i7 de junio donde, como he mencionado en otro apartado, el TC entiende que el anonimato del donante no supone la imposibilidad absoluta de determinar la identidad de los menores pues el precepto atribuye a los hijos el derecho a obtener la información general para garantizar el conocimiento de los factores o elementos genéticos de su progenitor, si bien recalca que todo ello a reserva de la identidad del

\footnotetext{
${ }^{3 \mathrm{I}}$ Entre ella, quizás quién con más fuerza ha defendido la existencia del mismo ha sido RIVERO HERNÁNDEZ. Este autor lo califica como un «derecho superior e inalienable» y considera que tiene su fundamento constitucional en los arts. Io y I8 CE y que ya la doctrina alemana y la jurisprudencia de su Tribunal Constitucional federal consideraron el derecho a conocer el propio origen biológico como un derecho fundamental, « ¿Mater semper certa est? Problemas de la determinación de la maternidad en el ordenamiento español», Anuario de derecho civil, Vol. 50, núm. I, I997, págs. 22-27.

${ }^{32}$ Así lo sostiene QuesadA GonZÁlEz, que afirma que el derecho a conocer el propio origen contribuye a lograr el desarrollo de la personalidad desde la perspectiva moral, pues una vez averiguada la filiación, podrá ser determinada y los padres biológicos atender a las necesidades del hijo; y desde la perspectiva espiritual, pues potencia el libre desarrollo de la personalidad del hijo con el afecto del padre o, al menos, haciendo que tenga constancia de su identidad, «El derecho (¿constitucional?) a conocer el propio origen biológico», Anuario de derecho civil, Vol. 47, núm. 2, I994, págs. 245-255.

${ }^{33}$ Así, por ejemplo, VIDAL PRAdo, quien admite que los hijos «sin excepción» tienen derecho a conocer su origen y filiación biológica y fundamenta este derecho en el art. 39.2 CE, que posibilita la investigación de la paternidad, junto con los arts. IO, I4 e incluso I5 CE, «El derecho a conocer la filiación biológica (con especial atención a la filiación materna)», Revista jurídica de Navarra, núm. 22, I996, págs. 266-270.

No obstante, RocA TRÍAs entiende que la investigación de la paternidad «no se concibe como un derecho del hijo cuya finalidad sea el conocimiento de la identidad de los padres, sino como un derecho concebido para que se descubra quién es el obligado a prestarle la protección que le es debida, según dispone el mismo art. 39·3 CE», «Filiación asistida y...», cit., pág. 5 .

${ }^{34}$ Vidal Prado, C., ibídem., pág. 269.

${ }^{35}$ Quesada GonZÁlez, «El derecho (¿constitucional?)...», cit., pág. 255.
} 
donante. No obstante, puede que solo con el conocimiento de estos datos no se respete el derecho a conocer el propio origen ${ }^{36}$.

Por último, resta por añadir que, si bien habitualmente se alude al derecho a conocer el propio origen en relación con el conocimiento de la paternidad, también tiene relación en el caso de la maternidad ${ }^{37}$. En este sentido fue importante la Sentencia del Tribunal Europeo de Derechos Humanos (TEDH), de I3 de febrero de 2003, en el asunto Odièvre contra Francia donde se discutía entre el derecho de los hijos a conocer sus orígenes y el derecho de la madre a conservar su identidad en secreto. El TEDH estimó que no había violación del art. 8 de la Convención ni del art. I4, que era lo que alegaba la demandante que solicitaba conocer sus orígenes. También es de interés la STS 776/1999, de 21 de septiembre hasta el punto de considerarla la doctrina como un hito muy importante en la evolución del derecho español en cuanto a la determinación de la maternidad y el derecho del hijo a conocer su origen. Esta sentencia considera derogado por inconstitucionalidad sobrevenida el art. 47.I de la Ley del Registro Civil de I957 y la inaplicación de los arts. I67 y I82 del Reglamento que lo desarrollan, por derogación de la cobertura legal. Estos artículos permitían a la madre negarse a que figurara su nombre en el parte médico y en la inscripción así como ocultar su identidad desde el momento del nacimiento, lo que el TS consideró que era contrario al principio de libre investigación de la paternidad y el de igualdad, así como contrario al art. Io CE por afectar a la dignidad de madre e hijo, a sus derechos inviolables que le son inherentes y al libre desarrollo de su personalidad ${ }^{38}$.

${ }^{36}$ Romero Coloma, A.M., «La identidad genética y la intimidad: un conflicto de derechos», Actualidad jurídica Aranzadi, núm. 789, 2009, pág. 4 versión digital.

${ }^{37}$ Vid. Rivero Hernández, F., «De nuevo sobre el derecho a conocer el propio origen. El asunto Odièvre (sentencia del Tribunal Europeo de Derechos Humanos de I3 de febrero de 2003)», Actualidad Civil, núm. 2, 2003, págs. 593-632; VIDAl Prado, C., «El derecho a...», cit., págs. 270-282; NieTA Alonso, A., «El derecho constitucional a conocer el propio origen biológico», Dereito: Revista xuridica da Universidade de Santiago de Compostela, Vol. I3, núm. I, 2004, págs. I49-I55.

${ }^{38}$ STS de 2I de septiembre de I999: «En la actualidad, y tras la vigencia de la Constitución de 1978 entendemos que tal limitación, elusiva de la constancia clínica de la identidad de la madre, ha quedado derogada por su manifiesta oposición a lo en ella establecido (...). En concreto, el sistema diseñado en los artículos I67, I82 y concordantes del Reglamento del Registro Civil, y sus disposiciones de desarrollo pugnan con el principio de libre investigación de la paternidad (artículo 39.2 de la Constitución española), y con el de igualdad (artículo I4), además de erosionar gravemente el artículo io de la Constitución Española, al afectar a la misma dignidad de madre e hijo, a sus derechos inviolables inherentes a ella, y al libre desarrollo de su personalidad (...). La coincidencia entre filiación legal y paternidad y maternidad biológica deben ser totales. Esta es la base desde la que decae la regulación reglamentaria permisiva de tal ocultación (...). La regulación reglamentaria del Registro Civil supone una contradicción con el principio constitucional de igualdad e investigación libre de la paternidad, al situar a la madre biológica en situación relevante frente al padre, e incluso frente al mismo hijo, ya que al padre se le puede imponer coactivamente la paternidad, en tanto que la madre, que puede determinar libremente si va a continuar la gestación o cortar por completo sus relaciones con la persona nacida, tiene el camino despejado para eludir sus obligaciones. El hijo biológico, además, pierde por completo el nexo que le permitiría, en su momento, conocer su verdadera filiación, debido a un acto voluntario de la madre, expresivo de su no asunción de la maternidad y sus responsabilidades inherentes. Por último, el sistema encierra graves discordancias, no sólo con relación a los mismos padre e hijo biológicos, sino también frente a la unión matrimonial, en la que la madre no puede renunciar a su maternidad ni negar al hijo el hecho de su filiación, ni el padre deshacer por sí solo la presunción de su paternidad, lo que no resulta constitucionalmente congruente máxime, cuando las investigaciones científicas tienden, en la actualidad, a poner de relieve las interrelaciones biológicas que se desprenden de los antecedentes genéticos y su influencia, de manera, que cabe hablar del derecho de las personas a conocer su herencia genética». 
En este sentido, actualmente el art. 44 de la Ley 20/20II, de 2I de julio, del Registro Civil (LRC) dispone que la inscripción de nacimiento se practicará en virtud de declaración formulada por los progenitores acompañada del parte facultativo y, a estos efectos, los médicos o enfermeros que asistan al nacimiento comprobarán la identidad de la madre del nacido. Además, se añade que en toda inscripción de nacimiento que tenga lugar en España (salvo los casos a que se refiere el art. 48 en caso de menores abandonados y menores no inscritos) debe hacerse constar necesariamente la filiación materna, aunque la madre puede solicitar que el acceso a la misma sea restringido por motivos fundados y siempre que renuncie a ejercer los derechos derivados de dicha filiación. Asimismo, si lo dispuesto en la declaración y en el parte facultativo no coinciden prevalecerá éste último. Además, en el art. 46 se obliga a que el personal sanitario que asista al nacimiento realice las comprobaciones necesarias para establecer de forma indubitada la filiación materna y deberán constar en el mismo documento las dos huellas plantares del recién nacido junto a las huellas dactilares de la madre. Por todo ello, la madre no podrá ocultar su identidad.

\section{Determinación de la filiación derivada de las técnicas de reproducción asistida}

\section{IV.I. Consideraciones previas}

Una concreta situación de facto como es la relación entre unos padres y sus hijos no se convierte en una situación de iure hasta que la filiación es determinada. Es decir, la relación de los padres con sus hijos una vez nacidos éstos no tendrá eficacia jurídica hasta que se determine la filiación. Esta determinación de la filiación podrá realizarse por vía extrajudicial o judicial.

Es precisamente la determinación de la filiación lo que mayores problemas plantea en relación con la aplicación de las técnicas de reproducción asistida. Según he aclarado anteriormente, para determinar la filiación de los nacidos mediante el uso de estas técnicas habrá que acudir, siguiendo el tenor literal del art. 7.I LTRHA, a las leyes civiles, remisión que se entiende hecha al Código civil y a las leyes autonómicas que regulan esta materia, sin perjuicio de las especificaciones que la LTRHA contempla en los arts. 7.3, 8, 9 y го. El problema viene dado porque la regulación de la determinación de la filiación en el Código civil tiende a hacer coincidir al padre biológico con el jurídico, mientras que la LTRHA se aparta del hecho biológico e instituye como padre o madre jurídico a quien ha prestado el consentimiento para la aplicación de estas técnicas, dando así preponderancia al elemento volitivo. No obstante, el consentimiento no será suficiente para determinar la filiación sino que dependiendo de si estamos ante filiación matrimonial o no matrimonial deberá atenderse a los diferentes títulos de determinación que para una y otra recoge el Código civil. Este será el procedimiento a seguir para determinar la filiación, con la excepción del supuesto contemplado en el art. 7.3 LTRHA donde el simple consentimiento de la cónyuge que se somete a estas técnicas determinará la filiación del nacido a su favor ${ }^{39}$.

\footnotetext{
${ }^{39}$ Lo que, según BARBER Cárcamo, «no puede entenderse sino como un nuevo título de determinación de la filiación, ligado a la voluntad pero esencialmente distinto al reconocimiento», «Reproducción asistida y determinación de la filiación», REDUR, núm. 8, diciembre 20ıо, pág. 29.
} 
A la hora de analizar los supuestos de determinación de la filiación que se derivan de la aplicación de las técnicas de reproducción asistida habrá que partir, por tanto, de la diferenciación entre si media o no matrimonio y si la fecundación es heteróloga (con contribución de donante) u homóloga (el material reproductor es el del marido o varón no casado).

Antes de adentrarme en la explicación de cada uno de los supuestos conviene poner de manifiesto algunos aspectos de la regulación contenida en la LTRHA. Entre ellos el que recoge el art. 8.3, según el cual y, en relación con el anonimato del donante que prevé en su art. 5, nunca se determinará la filiación a favor del donante cuya identidad sea revelada por concurrir algunos de los supuestos que contempla el art. 5.5. También deja claro la LTRHA que la gestación por sustitución está prohibida en nuestro país y, como consecuencia de ello, el contrato por el cual se convenga este tipo de prácticas será nulo de pleno derecho y la filiación de los hijos nacidos por este método se determinará por el parto (art. Io). Además, la LTRHA permite dos supuestos especialmente polémicos como son la denominada «doble maternidad», legitimada por el art. 7·3, y la fecundación post mortem, llamada así a la fecundación de la mujer con el material reproductor de su marido o pareja de hecho tras la muerte de éstos siempre que se cumplan unos requisitos; sobre ello volveré más adelante.

Asimismo, el art. 7.2 LTHRA dispone que «en ningún caso, la inscripción en el Registro Civil reflejará datos de los que se pueda inferir el carácter de la generación», referencia que debe entenderse en el sentido, según VERDERA SERVER, de que la misma se ha originado como consecuencia de la aplicación de técnicas de reproducción asistida. Por otra parte, el citado autor considera que esta previsión es inoperante en muchas ocasiones ya que el Registro Civil será ajeno a ello con el simple hecho de que el declarante no manifieste nada acerca de que la filiación proviene de estas técnicas, lo que no tendrá lugar en los supuestos del art. 7.3, 8.2 y 9 LTRHA $^{40}$.

Por último resta añadir que, dada la importancia que la LTRHA da al consentimiento, éste deberá prestarse cumpliendo unos determinados requisitos: así, el art. 6.I dispone que la mujer que vaya a someterse a las técnicas deberá prestar su consentimiento escrito de manera libre, consciente y expresa; el art. 6.3 alude a que el cónyuge deberá igualmente dar su consentimiento que deberá ser anterior a la utilización de las técnicas y realizarse de forma libre, consciente y formal; y el art. 8.I se refiere a un consentimiento formal, previo y expreso. Que el consentimiento reúna o no estos requisitos puede tener trascendencia a la hora de determinar la filiación o en cuanto al régimen de acciones, como luego veremos.

Por tanto, sentadas estas premisas, paso a analizar cada supuesto concreto de determinación de la filiación derivada de las técnicas de reproducción asistida.

\footnotetext{
${ }^{40}$ Verdera Server, R., «Comentario a los artículos 7 y 8» en Cobacho Gómez, J.A. (Dir.), Comentarios a la Ley 14/2006, de 26 de mayo, sobre Técnicas de Reproducción Humana Asistida, Cizur Menor, Thomson-Aranzadi, 2007 , pág. 237.
} 
IV.2. Determinación extrajudicial

IV.2.I. Matrimonial

IV.2.I.I. Homóloga

Posiblemente el supuesto menos conflictivo de aquellos a los que da lugar la aplicación de las técnicas de reproducción asistida sea aquél en que se recurre a la fecundación homóloga en el seno de un matrimonio, es decir, cuando se produce la fecundación de la mujer con sus óvulos y el semen de su marido previo consentimiento prestado por éste (art. 6.3 LTRHA). Esto es así ya que en este supuesto coincidirán tanto el aspecto biológico como el jurídico, es decir, se producirá la identidad entre padres biológicos (los que aportan el material genético) y padres jurídicos (los que constan formalmente como padres) al igual que ocurre en una fecundación natural y no artificial. Mayores problemas plantea la fecundación homóloga post mortem, es decir, aquella que tiene lugar con semen del marido pero una vez fallecido éste.

\section{IV.2.I.I.I. Intervivos}

Como consecuencia de la coincidencia entre el elemento biológico y el jurídico, la LTRHA no establece ninguna especialidad en su articulado en cuanto a la determinación de la filiación, por lo que, atendiendo al art. 7.I se aplicarán las normas contenidas en el Código civil y, en concreto, como estamos ante un supuesto de filiación matrimonial, las contenidas en los arts. II5 a II9 Cc. Así, la determinación de la filiación del nacido en caso de fecundación asistida homóloga y mediando matrimonio será sencilla: la maternidad vendrá determinada por el parto, en aplicación de la regla romana mater semper certa est; y la paternidad se determinará a través de la presunción contenida en el art. II 6 Cc por la cual se considera padre al marido de la madre (también conforme a la regla del Derecho romano pater is est quem nuptiae demonstrant) cuando el hijo haya nacido después de la celebración del matrimonio y antes de los trescientos días siguientes a su disolución o separación de los cónyuges. Todo ello quedará acreditado con la inscripción del nacimiento junto con la de matrimonio de los padres (art. II5.I Cc).

Faltando la presunción de paternidad del marido por causa de separación legal o de hecho, el art. II8 Cc exige el consentimiento de ambos cónyuges para que el hijo sea inscrito como matrimonial. La coordinación de esta norma con el art. 6.3 LTRHA plantea problemas ya que no se exigen los mismos requisitos formales ni temporales pero se entiende que el consentimiento a la fecundación no equivale al consentimiento del marido para la inscripción del hijo como matrimonial, por lo que puede darse el caso de que el marido, pese a haber consentido al uso de las técnicas de reproducción asistida de su mujer con su material genético, no preste su consentimiento para que el nacido se inscriba como matrimonial ex art. II8 $\mathrm{Cc}^{4 \mathrm{r}}$. En este caso deberá determinarse la filiación judicialmente mediante el ejercicio de una acción de reclamación, como más adelante veremos.

\footnotetext{
${ }^{4 \mathrm{~T}}$ Verdera SerVer, R., ibídem., pág. 268 y $27 \mathrm{I}$.
} 


\section{IV.2.I.I.2. Post mortem}

Dentro de la fecundación homóloga en pareja casada también nos encontramos con el supuesto más conflictivo de la fecundación post mortem (que también puede llevarse a cabo por pareja no casada, como veremos más adelante). Bajo la rúbrica «Premoriencia del marido» la LTRHA regula en el art. 9 la filiación del hijo nacido mediante el empleo de las técnicas de reproducción asistida una vez ha fallecido uno de los progenitores, el padre, que será quien haya aportado previamente su material reproductor y éste se encuentre crioconservado o antes de su fallecimiento se hubieran constituido in vitro los preembriones con $\mathrm{su}$ material reproductor ${ }^{42}$. Como decía, la inclusión de este supuesto ha generado divergencias entre parte de la doctrina ya que permitiría, al igual que en el caso de la utilización de las técnicas por una mujer sola, que un hijo naciera sin la referencia de una figura paterna.

En su apartado primero el citado artículo recoge la regla general por la cual «no podrá determinarse legalmente la filiación ni reconocerse efecto o relación jurídica alguna entre el hijo nacido por la aplicación de las técnicas reguladas en esta Ley y el marido fallecido cuando el material reproductor de éste no se halle en el útero de la mujer en la fecha de la muerte del varón». Esta regla, no obstante, encuentra una excepción en el apartado segundo del art. 9 (y en el apartado tercero con respecto al varón no casado), conforme al cual si se cumplen unos requisitos se determinará la filiación del hijo a favor del marido fallecido. Los citados requisitos son los siguientes:

- Consentimiento del marido: este consentimiento tiene que reunir una serie de caracteres. Así, ha de ser personalísimo ${ }^{43}$, por lo que no puede prestarse por representante legal y debe identificar a la mujer que va a ser fecundada ${ }^{44}$. Asimismo, se resalta el carácter

${ }^{42}$ Así, según Rodríguez Guitián en el art. 9 LTRHA «se regulan dos hipótesis diferentes; una, la fecundación artificial post mortem en sentido estricto y, dos, la transferencia post mortem de preembriones (...) La diferencia entre ambas hipótesis es clara: en el caso de la inseminación artificial se fecunda a la viuda o compañera con semen del varón fallecido, de modo que estaríamos ante un hijo, no póstumo, sino postumísimo, esto es, procreado después de la muerte del padre. Por el contrario, en la transferencia de preembriones el hijo es concebido en vida de ambos padres (in vitro), aunque su implantación, gestación y alumbramiento ocurran una vez ya fallecido el padre» y alude a la diferencia de régimen jurídico que el art. 9 LTRHA da para uno y otro supuesto, «Nuevos dilemas jurídicos de la reproducción asistida en España: la reproducción post-mortem y la doble maternidad» en FARNós AMORós, E., y BENAVENTE MOREDA, P. (coord.), Treinta años de reproducción asistida en España: una mirada interdisciplinaria a un fenómeno global y actual, Madrid, Ministerio de Justicia, 2015, pág. 92.

${ }^{43}$ En este sentido, vid. Auto de la Audiencia Provincial de A Coruña, de 3 de noviembre de 2000 que entiende que el consentimiento del fallecido a la fecundación de su mujer no puede ser suplido por el «consentimiento de los parientes más próximos o una autorización judicial» debido a la exigencia «de la expresión de un consentimiento de naturaleza personalísima, y sobre el cual debió ser informado el cónyuge premuerto al someterse a la extracción correspondiente para el depósito de su semen».

También, más recientemente, vid. Auto de la Audiencia Provincial de Santa Cruz de Tenerife, de 2 de junio de 2 оло que deniega la autorización judicial que solicitaba la demandante para utilizar el material genético de su marido fallecido con el argumento de que «la autorización requerida al marido es personalísima, sin que pueda ser suplida por nadie, menos aun cuando ya se ha extinguido la personalidad civil por la muerte de la persona (artículo 32 del Cc), y formal, sin que quepa ser suplida por otras pruebas documentales o testificales» (pues la mujer había aportado un carta mecanografiada y firmada por su marido fallecido, su madre y su hermana).

${ }^{44}$ Fernández Campos, J.A., «Comentario al artículo 9» en CoвACho GómeZ, J.A. (Dir.), Comentarios a la Ley 14/2006, de 26 de mayo, sobre Técnicas de Reproducción Humana Asistida, Cizur Menor, Thomson-Aranzadi, 2007, págs. 327-328. 
de expreso del consentimiento, por lo que, a excepción del párrafo final del art. 9.2 (donde se admite un consentimiento presunto en caso de que con anterioridad al fallecimiento se hubiera constituido el preembrión) se entiende que no podrá deducirse el consentimiento del hecho de que el marido sí haya consentido en vida que su mujer se someta a las técnicas de reproducción asistida mediante la inseminación artificial con su material reproductor, pues en la fecundación post mortem se necesita un consentimiento específico ${ }^{45}$.

Además el consentimiento tiene que ser formal y el art.9.2 recoge las formas en que podrá prestarse: en el documento a que se refiere el art. 6.3, en escritura pública, en testamento o en documento de instrucciones previas. De esta forma, se amplían las formas en las que el marido podía prestar su consentimiento con la anterior regulación por LTRA, pues solo daba la posibilidad de prestarlo en escritura pública o testamento.

Por último, el consentimiento así prestado será revocable. Así lo dispone expresamente el art. 9.2 cuando dice que «el consentimiento para la aplicación de las técnicas en dichas circunstancias podrá ser revocado en cualquier momento anterior a la realización de aquéllas». El artículo no hace referencia sin embargo a la forma en que deberá hacerse constar la revocación, entendiendo parte de la doctrina que no será necesario utilizar el mismo instrumento por el cual se consintió pero sí deberá reunir los mismos requisitos exigidos para el consentimiento ${ }^{46}$, mientras que otra parte aboga por la utilización de la misma forma en que se prestó el consentimiento añadiendo además una nota de revocación que deberá notificarse a la mujer que va a someterse a las técnicas y al Centro $^{47}$.

- Plazo de i2 meses desde el fallecimiento hasta la fecundación de la mujer con su material reproductor. Este plazo ha sido ampliado conforme a la regulación anterior por LTRA, en la que se contemplaba un plazo de 6 meses, que fue considerado como breve por parte de la doctrina.

Pues bien, cumpliéndose estos requisitos la mujer del fallecido podrá ser inseminada con el material reproductor de su marido, dando a luz a un hijo que verá determinada su filiación materna a favor de aquélla y su filiación paterna a favor del marido fallecido que previamente había aportado su material reproductor. Aunque fue discutida la consideración de esta filiación como matrimonial o no en el sentido de que al concebirse el hijo no mediaba matrimonio ya que el marido había fallecido y por la dificultad de que se

\footnotetext{
${ }^{45}$ El Auto del Juzgado de Primera Instancia de Valladolid, de I2 de diciembre de 2007 alude a la importancia de que conste expresamente el consentimiento del fallecido pues «sin una voluntad expresa es extremadamente difícil saber si la persona ya fallecida hubiera querido que naciera un hijo suyo al que nunca podría criar o conocer» y deniega la autorización solicitada por la mujer del fallecido para usar el material genético de su marido ya que no se ha prestado el consentimiento ni en escritura pública, ni testamento, ni en documento de instrucciones previas y que el consentimiento prestado en el documento a que se refiere el art. 6.3 a que su mujer se someta a las técnicas no determina per se el consentimiento para que se utilice su material genético después de su muerte, debiendo manifestarse el marido expresamente sobre este particular en el citado documento.

${ }^{46}$ GonZÁles Pérez De Castro, M., La verdad biológica..., cit., pág. 273.

${ }^{47}$ Expresa esta opinión PÉREz MONGE, si bien lo hace vigente la LTRA cuando solo se podía prestar el consentimiento mediante escritura pública o testamento sin posibilidad de hacerlo en documento privado, $L a$ filiación derivada de técnicas de reproducción asistida, Madrid, Colegio de Registradores, 2002, pág. 278.
} 
cumplieran los plazos de la presunción de paternidad que recoge el art. II6 Cc (300 días desde la disolución del matrimonio), la LTRA primero y, en iguales términos la LTRHA dispone expresamente que «la generación producirá los efectos legales que se derivan de la filiación matrimonial», incluidos los derechos sucesorios ${ }^{48}$.

\section{IV.2.I.2. Heteróloga}

La fecundación heteróloga tiene lugar cuando la mujer es inseminada con material reproductor de un donante. Este tipo de prácticas puede llevarse a cabo tanto por pareja casada como por pareja no casada pero en este apartado me centraré en el supuesto de la fecundación heretóloga realizada en el seno de un matrimonio y, por tanto, en la generación de un hijo cuya filiación será matrimonial. Esto por lo que respecta a un matrimonio heterosexual, pero no hay que olvidar que los matrimonios homosexuales también pueden hacer uso de las técnicas de reproducción asistida y, desde el año 2007, la LTRHA prevé la posibilidad de que un niño nacido de una mujer que ha acudido a la reproducción asistida con material genético de donante pueda ver determinada su filiación, además de a favor de su madre biológica, a favor de la cónyuge de ésta, como veremos más adelante.

\section{IV.2.I.2.I. Matrimonio heterosexual}

Para analizar este supuesto hay que partir de que la LTRHA sí que lo contempla en su regulación. En concreto, se refiere a la fecundación heteróloga en caso de matrimonio el art. 8. I que dice lo siguiente: «Ni la mujer progenitora ni el marido, cuando hayan prestado su consentimiento formal, previo y expreso a determinada fecundación con contribución de donante o donantes, podrán impugnar la filiación matrimonial del hijo nacido como consecuencia de tal fecundación». Como se puede apreciar, este artículo, aunque regula el supuesto, no dice nada acerca de la determinación extrajudicial de la filiación sino que dispone que el consentimiento prestado por el marido para la fecundación de su mujer con material reproductor de un donante llevará a que ni la mujer progenitora ni su marido puedan ejercitar una acción de impugnación de la filiación matrimonial del hijo así nacido. No obstante, aunque el artículo no diga nada acerca de la determinación de la paternidad, el consentimiento prestado por el marido es el elemento determinante, junto con la imposibilidad de impugnar la filiación, para que se determine a su favor la filiación ${ }^{49}$. Así, por tanto, aunque el marido no sea el padre biológico, la filiación se determinará a su favor, con lo que se pone de relieve la prevalencia del elemento volitivo frente al biológico, pues el donante, que es quien aporta su material genético, nunca verá determinada la filiación a su favor en virtud del art. 8.3 LTRHA.

\footnotetext{
$4^{48}$ Fernández Campos, J.A., «Comentario al...», cit., págs. 350-352.

${ }^{49}$ Verdera SERVER: «La falta de paternidad genética se suple con la manifestación del consentimiento del marido y de la madre que se revelan elementos decisivos en la imputación de la paternidad. El art. 8.I LTRHA no formula norma en sentido positivo sobre esta imputación de la paternidad, sino que se alcanza esa conclusión a la vista de la imposibilidad de impugnar la paternidad del hijo nacido de una fecundación con contribución de donante, si se ha prestado el consentimiento a la misma», «Comentario a los...», cit., pág. 27I y 272.
} 
No quiere ello decir que se atribuya al consentimiento la característica de título de determinación de la filiación sino que, más bien, volveríamos a encontrarnos con la necesidad de acudir ex art. 7.I LTRHA a las reglas contenidas en el Código civil para la determinación de la filiación matrimonial. Por tanto, se determinará la filiación del hijo nacido mediante las técnicas de reproducción asistida a favor del marido que ha dado su consentimiento (aunque, reitero, sin ser realmente él su padre genético) atendiendo a la presunción de paternidad del art. Iı6 Cc.

No obstante, del mismo modo que el consentimiento no es un título de determinación de la filiación, tampoco es el elemento que hace que entre en juego la presunción de paternidad del art. ıı6, pues ésta es automática. Es decir, el hijo nacido de una mujer que se somete a las técnicas de reproducción asistida con contribución de donante se presumirá hijo del marido de aquélla haya o no prestado su consentimiento a la reproducción asistida de su mujer en virtud de la presunción de paternidad. Como consecuencia de ello la LTRHA da mucha importancia a la prestación del consentimiento y el art. 8.I LTRHA se refiere a que éste deberá ser formal, previo y expreso a la fecundación con contribución de donante. La falta de consentimiento por parte del marido o los vicios en el consentimiento prestado abrirá la puerta a la posibilidad de impugnar la filiación, como explicaré más adelante al hablar de las acciones de filiación, si bien podría también el marido destruir la presunción de paternidad en virtud del art. II7 Cc siempre que se cumplan los plazos que el citado artículo recoge, es decir, el nacimiento del niño entre la celebración del matrimonio y los ciento ochenta días siguientes.

\section{IV.2.I.2.2. Matrimonio homosexual: doble maternidad por naturaleza}

Hasta aquí he hecho referencia en todo momento al matrimonio heterosexual, pero tras la reforma en el año 2007 de la LTRHA se favorece que un matrimonio homosexual, en este caso de mujeres, pueda ver determinada la filiación del hijo nacido a favor de las dos mujeres que conforman el matrimonio, dando lugar a lo que ha venido a llamarse «doble maternidad por naturaleza».

La reforma del art.7 LTRHA por Ley 3/2007, de I5 de marzo, reguladora de la rectificación registral de la mención relativa al sexo de las personas es consecuencia de la admisión del matrimonio homosexual por la Ley 13/2005, de I de julio, por la que se modifica el Código Civil en materia de derecho a contraer matrimonio. Esta Ley permitió el matrimonio entre personas del mismo sexo y también posibilitó la adopción conjunta por ambos miembros de la pareja o la adopción del hijo de uno de ellos por su cónyuge. Así, estaríamos ante un supuesto de filiación adoptiva (si los dos cónyuges adoptan conjuntamente) y ante una filiación por naturaleza en un caso y adoptiva en otro (si es un miembro de la pareja el que adopta al hijo del otro miembro cuya filiación ya está determinada), pero nunca se podía dar el caso de una filiación por naturaleza doble. Esto fue así hasta que se produjo la citada reforma del art. 7 LTRHA solo un año después de la entrada en vigor de la Ley, posibilitando la doble maternidad por naturaleza al permitir que la cónyuge de la mujer que ha dado a luz un hijo mediante reproducción asistida dé su consentimiento para que se determine a su favor la filiación de ese hijo. 
El supuesto contemplado por el art. 7.3 LTRHA ha recibido por parte de la doctrina críticas que, sumadas a la forma de incorporar el precepto por Disposición Adicional de una Ley solo un año posterior a la LTRHA ${ }^{50}$, se centran en la figura en sí misma ${ }^{5 \mathrm{I}}$ y en algunos aspectos concretos. Así, ha sido objeto de críticas desde por su ubicación en la Ley ${ }^{52}$ hasta por la posible discriminación a que da lugar en un doble sentido: el precepto solo se aplica en caso de matrimonio homosexual de mujeres, por lo que obvia, por un lado, la posibilidad de que este mismo supuesto pueda ser aplicado a matrimonio homosexual de hombres (pues si fuera de hombres nos conduciría inevitablemente al supuesto de la maternidad subrogada, lo que, como veremos, está prohibido en nuestro país) y, por otro lado, que pueda aplicarse por una pareja de mujeres no casadas $^{53}$, aunque en este último aspecto también hay parte de la doctrina que sostiene la no discriminación ${ }^{54}$. De igual modo se ha cuestionado su inclusión como un modo de filiación natural por la mayor aproximación del supuesto a la filiación adoptiva, sin embargo para determinar esta filiación no media ni resolución judicial ni se somete al principio del interés del adoptando por lo que habida cuenta de que no hay un tercer tipo de filiación distinto de la filiación por naturaleza y la

\footnotetext{
${ }^{50}$ Calificado por Verdera SERVER como inapropiado «por cuanto incide en una Ley que no tenía ni un año de vigencia y por cuanto recupera una cuestión que fue debatida en la tramitación parlamentaria de la Ley de Técnicas de Reproducción Humana Asistida y rechazada en su momento», y sostiene que «no hay ninguna justificación aparente del cambio legislativo en tan corto espacio de tiempo» ya que «la falta de regulación ya se producía (y así se puso de manifiesto en el debate parlamentario) en 2006», «Comentario a los...», cit., págs. 28I y 282.
}

${ }^{51}$ Se opone a ella BARBER CÁRCAMO: «En este supuesto excepcional, no sólo para el sistema codicial de filiación natural, sino para el resultante de la propia LTRHA en que se ubica, el legislador admite una filiación natural matrimonial imposible, desligada ya no de la verdad, sino de la posibilidad biológica, con una aproximación técnica tan pobre como insuficiente», La Filiación en..., cit., pág. I36.

${ }^{52}$ La cual, en palabras de BARBER CÁRCAMO, es «expresiva de una contradicción insalvable con el párrafo anterior, que prohíbe incluir datos en la inscripción registral reveladores del carácter asistido de la generación» y, «dado que el precepto contempla una norma relativa a la determinación legal de la filiación, hubiera encontrado acomodo más propio en el art. 8, que así se titula, además de enlazar mejor con lo previsto en el art. 7.I», «Doble maternidad legal, filiación y relaciones parentales», Derecho Privado y Constitución, núm. 28, enero-diciembre 2014, pág. IO3.

${ }^{53}$ Entiende DíAZ MARTínEZ que «resulta sorprendente que el legislador estatal no haya extendido el mismo régimen a las parejas de mujeres no casadas, pues sí aparecen contempladas en materia de reproducción asistida desde la perspectiva de la determinación de la doble relación de filiación, ya desde el texto legal de iو88, las heterosexuales» y aboga por una aplicación analógica del art. 8.2 LTRHA, «La doble maternidad legal derivada de la utilización de técnicas de reproducción humana asistida», Derecho Privado y Constitución, núm. 2I, enero-diciembre 2007, págs. I07 y 108.

También lo considera como una «distinción no justificada» TAMAYO HAYA ya que «en cierto sentido discrimina frente al compañero estable de la mujer que ha dado su consentimiento a la inseminación artificial con su semen o el de un tercero» y aboga igualmente por que esto «se aplique analógicamente al supuesto de mujeres que convivan more uxorio», «Hacia un nuevo...», cit., pág. 280.

${ }^{54}$ Entre ellos BARBER CÁRCAMO con doble motivo: en relación con la diferencia de trato entre el matrimonio homosexual de mujeres y la unión de hecho afirma que «cabe justificar la opción del legislador en el argumento de la estabilidad matrimonial frente a la unión de hecho y en la inexistencia, en el Derecho común, de una regla que exija la equiparación entre el matrimonio y las uniones de hecho» y, en la comparación entre parejas de hecho heterosexuales y homosexuales, entiende que no hay discriminación «porque la diferencia objetiva y relevante entre ellas viene dada por la posibilidad de filiación que en éstas (en las parejas de hecho heterosexuales) se da, no presente en las homosexuales» y afirma que es la «posibilidad de relación biológica a partir de la oposición sexual» en la pareja heterosexual en contraposición a la homosexual (donde es imposible una relación biológica fértil) lo que justifica que en el primer caso «el legislador reconduzca los títulos de determinación de la filiación asistida a los habituales» y en el segundo los excluya, «Doble maternidad...», cit., pág. I05. 
filiación adoptiva, debería entenderse que el supuesto contemplado en el art. 7.3 LTRHA es un supuesto de filiación por naturaleza ${ }^{55}$. Por último, con respecto al carácter matrimonial o no de esta filiación derivada del art. 7.3 LTRHA, debe calificarse como matrimonial debido a que entre las dos mujeres que van a ser consideradas como madres debe mediar obligatoriamente matrimonio pues, como he dicho, el precepto no contempla otra posibilidad $^{56}$.

Pues bien, partiendo de la ya citada regla mater semper certa est la mujer que se ha sometido a las técnicas de reproducción asistida con material genético procedente de un donante y que, por tanto, será la mujer gestante y la que da a luz, verá determinada a su favor, como es lógico, la filiación materna del nacido. En cuanto a la cónyuge de la madre gestante, en virtud del ya mencionado art. 7.3 LTRHA podrá ser considerada también como madre si presta su consentimiento, el cual deberá reunir una serie de requisitos que son los siguientes:

- En cuanto al momento de prestar el consentimiento, la redacción del art. 7.3 exigía hacerlo mediando matrimonio entre las mujeres, sin que hubiera separación legal o de hecho, y antes del nacimiento del hijo (pues expresaba que la determinación de la filiación se produciría «cuando nazca el hijo de su cónyuge»). Mientras que la necesidad de que el consentimiento se preste una vez se haya celebrado matrimonio sigue vigente, el requisito de realizarlo en un momento anterior al nacimiento del hijo se ha suprimido con la reciente modificación que del apartado tercero del art. 7 LTRHA ha realizado la Ley I9/2015, de I3 de julio, de medidas de reforma administrativa en el ámbito de la Administración de Justicia y del Registro Civil. Así, desde el I5 de octubre de 2015, momento en que entró en vigor la citada Ley, ya no es requisito indispensable que la cónyuge preste el consentimiento en un momento anterior al nacimiento del hijo, por lo que podrá prestarlo antes o después del mismo.

- La manifestación del consentimiento debe realizarse mediante una declaración registral conforme a lo dispuesto en la Ley del Registro Civil que, actualmente y también tras la reforma por Ley I9/20I5, dispone en su artículo 44.5 que «también constará como filiación matrimonial cuando la madre estuviere casada, y no separada legalmente o de hecho, con otra mujer y esta última manifestara que consiente en que se determine a su favor la filiación respecto al hijo nacido de su cónyuge».

Concurriendo estos requisitos, el consentimiento prestado por la cónyuge de la mujer que da a luz hará que se le atribuya directamente la filiación del nacido, constando en el Registro Civil también como madre y quebrando con la regla por la cual la determinación de la maternidad se produce por el parto. Este consentimiento en orden a la determinación de la filiación se diferencia del consentimiento para autorizar el uso de las técnicas de

\footnotetext{
${ }^{55}$ BARber CÁRCAMO, R., ibídem., pág. iII y iI2, nota 32.

${ }^{56}$ Verdera SeRVER: «El art. 7.3 LTRHA no se pronuncia acerca del carácter de la filiación de ese hijo con doble maternidad. En nuestra opinión, debe ser calificado de filiación matrimonial en la medida que quienes son considerados jurídicamente como padres están casados entre sí (art. Io8.I Cc)», «Comentario a los...», cit., pág. 288.
} 
reproducción asistida ${ }^{57} y$, en este sentido, que sea el consentimiento lo que determina la filiación sin necesidad de acudir posteriormente a los títulos de determinación de la filiación del Código civil hace que la doctrina entienda que estamos ante un nuevo título de determinación de la filiación ${ }^{58}$. Además es necesario poner de manifiesto que no se alude en ningún momento a la necesidad de que la cónyuge que da a luz preste también su consentimiento a que se determine a favor de su cónyuge la filiación del nacido ${ }^{59}$.

Por lo demás, cabe decir para concluir con este apartado, que la no concurrencia de los requisitos a los que he hecho referencia para la aplicación del art. 7.3 LTRHA antes de la reforma del año 20I5, es decir, que faltara la declaración de la cónyuge de la mujer gestante antes del nacimiento o que no mediara matrimonio, han venido supliéndose por la jurisprudencia determinando judicialmente la filiación, como pondré de manifiesto en el apartado de la determinación judicial de la filiación.

\section{IV.2.2. No matrimonial}

\section{IV.2.2.I. Homóloga}

\section{IV.2.2.I.I. Intervivos}

Al igual que en el caso de la fecundación homóloga en pareja casada, tampoco plantea mayores problemas la fecundación homóloga si se realiza en una pareja no casada. De igual manera, por tanto, la LTRHA no contempla especialidades para este supuesto y ex art.7.I habrá que acudir a las reglas que, para la filiación no matrimonial, recoge el Código civil en sus arts. I20 a I26. De este modo, como en la filiación no matrimonial no rige la presunción de paternidad, el padre deberá acudir a los títulos de determinación de la filiación no matrimonial que recoge el art. I20 Cc y que son, principalmente, el reconocimiento ante el encargado del Registro Civil y la resolución derivada de un expediente registral, a los que desde la reforma por Ley I9/2015, de I3 de julio, de medidas de reforma administrativa en el ámbito de la Administración de Justicia y del Registro Civil, se une la declaración conforme realizada por el padre en el formulario oficial en el momento de la inscripción del nacimiento (art. I20.. ${ }^{\circ} \mathrm{Cc}$ ). En este sentido hay que tener en cuenta la importancia que en relación con el reconocimiento y el expediente registral puede tener el consentimiento prestado para la utilización de estas técnicas. Así, siguiendo a

\footnotetext{
${ }^{57}$ RodRíGueZ GuITIÁN: «Es muy importante caer en la cuenta de que el consentimiento al que se refiere el artículo 7.3 LTRHA es muy distinto al consentimiento para autorizar el uso de las técnicas de reproducción asistida, consentimiento este último al que en ningún momento se refiere el legislador cuando regula la doble maternidad. El consentimiento al que alude tal precepto se hace para la determinación de la filiación de nacido a favor de la cónyuge declarante no gestante», «Nuevos dilemas...», cit., pág. I30.

${ }^{58}$ Vid. BARBER CÁRCAMO, R., «Reproducción asistida y...», cit., pág. 29.

${ }^{59}$ MARTínez De Aguirre AldAZ: «Es muy llamativa, por contraste, la ausencia de cualquier tipo de control o contrapeso a la voluntad de la esposa declarante: el establecimiento de la filiación depende exclusivamente de su voluntad, a diferencia de lo que ocurre con otros supuestos en los que la voluntad juega un papel decisivo en el establecimiento de la filiación (...). En esta línea, llama la atención que no se tome en consideración a ningún efecto la voluntad de la madre biológica (la esposa que da a luz) -la cual, por otro lado, ha podido someterse a estas técnicas sin necesitar el consentimiento previo de su esposa-», «Capítulo I4. Acciones de filiación. Filiación derivada de técnicas de reproducción asistida», en MARTínez De Aguirre Aldaz, C. (coord.), Curso de Derecho Civil IV. Derecho de Familia, Madrid, Colex, 2013, pág. 348.
} 
VERDERA SERVER, el consentimiento prestado para la práctica de la fecundación no reúne las exigencias formales que precisa el art. i2o Cc para llevar a cabo el reconocimiento, por lo que «la expresión del consentimiento a esas técnicas de reproducción asistida no excluye la necesidad de que quien pretenda reconocer su paternidad vuelva a prestar su consentimiento para que se determine extrajudicialmente esa filiación»; y, en cuanto al expediente registral para determinar la paternidad, las circunstancias en las que puede basarse el mismo son las recogidas actualmente en el art. 44 apartado séptimo LRC y que son: la existencia de un escrito indubitado del padre reconociendo la filiación y la posesión de estado de hijo del padre. En relación con el escrito indubitado, el art. 8.2 LTRHA, aplicable para el caso de fecundación heteróloga en caso de pareja no casada, dispone que se considera como tal «a los efectos previstos en el apartado 8 del artículo 44 de la Ley 20/20II, de 2I de julio, del Registro Civil» ${ }^{60}$, al documento por el que se consiente la fecundación; pero este artículo, en principio, no sería aplicable al supuesto que ahora nos ocupa, si bien entiende VERDERA SERVER que podrá aplicarse analógicamente ${ }^{6 \mathrm{I}}$.

\section{IV.2.2.I.2. Post mortem}

Del mismo modo que en el caso de filiación matrimonial derivada de la aplicación de técnicas de reproducción asistida homólogas, también cabe la filiación no matrimonial del hijo nacido por fecundación post mortem. Aquí cabe traer a colación todo lo visto al explicar la fecundación post mortem en caso de pareja casada ${ }^{62}$ debiendo prestar el varón el consentimiento de la misma forma y en los mismos plazos en virtud del art. 9.3 LTRHA, que se remite a la posibilidad prevista en el apartado anterior para el caso de pareja casada. La diferencia a la hora de determinar la filiación del nacido haciendo uso de la fecundación post mortem viene dada porque el consentimiento prestado por el varón servirá como título para iniciar el expediente registral regulado en el art. 44.7 LRC.

\section{IV.2.2.2. Heteróloga}

Una mujer que no haya contraído matrimonio puede igualmente someterse a las técnicas de reproducción asistida con contribución de donante. En este sentido se dan dos posibilidades: la primera, cuando lo realice con el consentimiento del varón con el que no ha contraído matrimonio (conviva o no con él), en cuyo caso el hijo así concebido verá determinada su paternidad a favor de dicho varón que haya prestado su consentimiento a la inseminación artificial de su pareja con material genético de un donante; y, la segunda, haciéndolo en solitario, pues la LTRHA permite que una mujer que no tiene pareja puede someterse sin mayor inconveniente a las técnicas de reproducción asistida con contribución

\footnotetext{
${ }^{60}$ Aunque el art. 8.2 LTRHA disponga literalmente que «Se considera escrito indubitado a los efectos previstos en el apartado 8 del artículo 44 de la Ley 20/20II, de 2I de julio, del Registro Civil el documento extendido ante el centro o servicio autorizado en el que se refleje el consentimiento (...)» la referencia es errónea ya que se refiere, en realidad, al apartado 7 del art. 44 de la citada Ley, que es donde se regula el expediente registral, y no en el apartado 8. El mismo error aparece en el art. 9.3 LTRHA, por lo que habrá que entender que se refiere al apartado 7 del art. 44 de la Ley $20 / 20$ II.

${ }^{61}$ Verdera SERVER, R., «Comentario a los...», cit., págs. 293 y 294.

${ }^{62}$ Vid. apartado IV.2.I.I.2
} 
de un donante, en cuyo caso, el nacido solo verá determinada su filiación materna y no la paterna pues, como ya he dicho en varias ocasiones, al donante nunca se le atribuirá la filiación del nacido con su material genético. En ambos casos estaremos ante una filiación no matrimonial.

\section{IV.2.2.2.I. Con consentimiento del varón no casado}

En la primera de estas dos posibilidades, es decir, que la mujer se someta a la inseminación con material genético del donante y lo realice con consentimiento de su pareja, como ya adelantaba, el varón verá determinada a su favor la filiación del nacido. Para ello, deberá haber prestado su consentimiento en el documento extendido ante el centro o servicio autorizado y lo deberá haber hecho con anterioridad al empleo de las técnicas (art. 8.2 LTRHA). Pero, una vez más, el consentimiento no determinará por sí solo la filiación, sino que deberá acudirse a los títulos de determinación extrajudicial de la filiación no matrimonial que recoge el Código civil en su art. I20. Lo que añade en este sentido el consentimiento prestado por el varón es que, según el art. 8.2 LTRHA se considera como un escrito indubitado a los efectos de tramitar el expediente registral que regula el art. 44.7 LRC.

\section{IV.2.2.2.2. Mujer en solitario}

Por lo que respecta a la segunda posibilidad, que la mujer se someta a las técnicas de reproducción asistida con contribución de donante pero haciéndolo en solitario, si bien la LTRHA no lo contempla expresamente, esta posibilidad se deduce (y así lo admite la doctrina y se plasma en la práctica) del art. 6.I LTRHA, que se refiere a que «toda mujer mayor de I8 años y con plena capacidad de obrar podrá ser receptora o usuaria de las técnicas regulada en esta Ley, siempre que haya prestado su consentimiento escrito a su utilización de manera libre, consciente y expresa». Así, con base en el hipotético derecho a procrear del que ya he hablado anteriormente, una mujer podrá a dar a luz a un hijo mediante inseminación artificial con semen de donante, quedando determinada legalmente solo la filiación materna.

\section{IV.3. Gestación por sustitución}

La gestación por sustitución puede definirse como el contrato en virtud del cual una persona o una pareja (pareja comitente o padres intencionales) acuerda con una tercera mujer (madre gestante o madre subrogada) que ésta se someta a técnicas de reproducción asistida y geste en su vientre un niño para que una vez que éste nazca sea entregado a aquéllos renunciando a su vez a la filiación sobre el niño gestado ${ }^{63}$.

La gestación por sustitución, técnica que también suele conocerse como maternidad subrogada o coloquialmente «vientre de alquiler», comprende diversos supuestos. Así,

\footnotetext{
${ }^{63}$ La SAP de Valencia, de 23 de noviembre de 20II lo define como: «contrato, oneroso o gratuito, a través del cual una mujer consiente en llevar a cabo la gestación, mediante técnicas de reproducción asistida, aportando o no también su óvulo, con el compromiso de entregar el nacido a los comitentes, que pueden ser una persona o una pareja, casada entre sí o no, que a su vez pueden aportar o no sus gametos».
} 
aunque tradicionalmente ha venido siendo utilizada por parejas heterosexuales que no podían tener hijos por problemas de infertilidad, actualmente también estas parejas recurren a estas técnicas sin padecer ese problema aunque, como es lógico, dada la posibilidad de fecundación natural, en menor medida. Además, también está siendo utilizada cada vez más por parejas homosexuales tanto de hombres (éstos obviamente con causa en su imposibilidad de tener hijos pero unido al deseo de que el niño/a porte material genético propio, ya que si no podrían acudir a la adopción para colmar el deseo aludido) como de mujeres (en menor medida debido a la posibilidad que les brinda el art. 7.3 LTRHA), así como por hombres o mujeres solteros. A su vez puede distinguirse entre una gestación por sustitución plena y parcial: mientras que la primera tiene lugar cuando la pareja comitente aporta el material reproductor (el óvulo de la mujer es fecundado con el semen del marido) que luego será transferido a la mujer gestante, la segunda viene dada por la inseminación con semen del padre comitente de la mujer que gestará al hijo (con lo que ésta última aporta el óvulo) ${ }^{64}$.

Pues bien, a pesar de todos estos supuestos en los que suele recurrirse a la gestación por sustitución, lo cierto es que esta técnica está prohibida en nuestro país y recurrir a ella tiene como sanción la nulidad del contrato. De este modo, el art. Io LTRHA dispone expresamente que «será nulo de pleno derecho el contrato por el que se convenga la gestación, con o sin precio, a cargo de una mujer que renuncia a la filiación materna a favor del contratante o de un tercero». La consecuencia directa que atribuye el segundo párrafo del citado artículo es que la filiación de los hijos nacidos por este método se determinará por el parto. Por tanto, el legislador recurre al criterio tradicional del mater semper certa est imponiendo que la filiación materna se determine a favor de la madre que ha gestado y dado a luz al niño, sin determinación a favor de la madre de intención; y la paterna podrá determinarse ejercitando la acción de reclamación de la paternidad del padre biológico que recoge el art. I0.3 LTRHA.

En este contexto cada vez es más común acudir al denominado «turismo reproductivo» para hacer realidad un deseo que en nuestro país está vedado y que supone realizar la gestación por sustitución en otros países donde ésta sí está permitida. Así, una vez realizada la gestación por sustitución en el extranjero se solicita la inscripción del nacimiento junto con la filiación en el Registro Civil español. Como consecuencia de esta práctica, personificada por el primer supuesto que vio la luz en España de un matrimonio homosexual que habiendo recurrido a la gestación por sustitución en California solicitaba la inscripción de dos certificados de nacimiento en los que constaba la filiación paterna de los dos hombres, la Dirección General de los Registros y del Notariado (DGRN) se vio obligada a dictar la Instrucción de 5 de octubre de 20ıo, sobre régimen registral de la filiación de los nacidos mediante gestación por sustitución. En esta Instrucción, la DGRN, «atendiendo a la finalidad de dotar de plena protección jurídica el interés superior del menor, así como de otros intereses preferentes en los supuestos de gestación por sustitución», establece los

\footnotetext{
${ }^{64}$ García Pérez, C.L, «Comentario al artículo io» en Cobacho Gómez, J.A. (Dir.), Comentarios a la Ley 14/2006, de 26 de mayo, sobre Técnicas de Reproducción Humana Asistida, Cizur Menor, Thomson-Aranzadi, 2007, pág. 366.
} 
criterios que se deben seguir para que tenga lugar el acceso al Registro Civil de los nacidos en el extranjero mediante gestación por sustitución. Así, el presupuesto que según la DGRN debe cumplirse para inscribir en el Registro Civil español el nacimiento y la filiación derivada del uso de la gestación por sustitución en el extranjero es la presentación de la solicitud de inscripción de un menor junto con una resolución judicial dictada por el Tribunal competente del país donde se realice la gestación por sustitución en el que se determine la filiación del nacido y excluye la simple presentación de una certificación registral extranjera acompañada de certificación médica relativa al nacimiento del menor en la que no conste la identidad de la madre gestante.

La citada Instrucción tiene como precedente la Resolución de la DGRN de I8 de febrero de 2009. Esta Resolución revocó el auto del encargado del Registro Civil Consular que había denegado, como decía antes, la inscripción del nacimiento de los hijos de un matrimonio homosexual nacidos mediante gestación por sustitución en California (que aportaban para ello unas certificaciones registrales extranjeras en las que constaba el nacimiento y la filiación) invocando la prohibición contenida en el art. IO.I LTRHA y la determinación de la filiación a favor de la madre gestante en virtud del art. I0.2 LTRHA. Pues bien, con fundamento en que el acceso al Registro Civil español de una certificación registral extranjera debe valorarse «no a través del Derecho sustantivo español ni a través de las normas de conflicto españolas, sino a través de las normas específicas que en Derecho español disciplinan el acceso de las certificaciones registrales extranjeras al Registro Civil español» que, en este caso, es el art. 8I del Reglamento del Registro Civil (RRC) y que llevaría a realizar un «control de legalidad» de la certificación registral extranjera y, también con fundamento en que la mencionada certificación no vulnera el orden público internacional español, la DGRN en la mencionada Resolución de I8 de febrero de 2009 ordenó la inscripción solicitada.

La Resolución fue recurrida ante el Juzgado de Primera Instancia de Valencia por el Ministerio Fiscal. Este Juzgado, por sentencia de I5 de septiembre de 20 Io estimó la demanda interpuesta y dejó sin efecto la inscripción de nacimiento. La SAP de Valencia de 23 de noviembre de $201 \mathrm{I}$ primero, y posteriormente la STS de 6 de febrero de 20I4, confirmaron el pronunciamiento del Juzgado de Primera Instancia de Valencia.

Sin ánimo exhaustivo, pues lo contrario haría que el análisis de estos pronunciamientos judiciales ocupara varias páginas de este trabajo, resumiré el pronunciamiento del Tribunal Supremo ${ }^{65}$. En primer lugar, el TS analiza si procede el reconocimiento por las autoridades del Registro Civil español de la inscripción de nacimiento realizada por las autoridades del Registro Civil de California en la que se fija la

\footnotetext{
${ }^{65}$ No obstante mucha doctrina se ha ocupado a fondo de comentar lo jurídicamente relevante en torno a la gestación por sustitución y todo este iter judicial mencionado. Así, por ejemplo, tres recientes pueden verse en: FARNós Amorós, E., «La filiación derivada de...», cit., págs. 30-49; VelA SÁNCHEZ, A.J., Gestación por encargo: tratamiento judicial y soluciones prácticas. La cuestión jurídica de las madres de alquiler, Madrid, Reus, 20I5; RoCA TRÍAS, E., «Dura lex sed lex. O de cómo integrar el interés del menor y la prohibición de la maternidad subrogada» en FARNós AMORós, E., y BENAVENTE MoredA, P. (coord.), Treinta años de reproducción asistida en España: una mirada interdisciplinaria a un fenómeno global $y$ actual, Madrid, Ministerio de Justicia, 20I5, págs. 30I-338.
} 
filiación de los dos hombres y si puede desplegar sus efectos en el sistema jurídico español. En este sentido, valiéndose del art. 23 LRC y los arts. 8I y 85 RRC entiende que debe realizarse un control de que la certificación del Registro extranjero es regular y auténtica, constata la realidad del hecho inscrito y es legal conforme a la Ley española, extendiendo el control no solo a los aspectos formales sino también a las cuestiones de fondo, lo que lleva a analizar si la certificación registral extranjera respeta el orden público internacional español. De este modo, el TS considera que «la decisión de la autoridad registral de California al atribuir la condición de padres al matrimonio que contrató la gestación por sustitución con una mujer que dio a luz en dicho Estado es contraria al orden público internacional español por resultar incompatible con normas que regulan aspectos esenciales de las relaciones familiares, en concreto de la filiación, inspiradas en los valores constitucionales de dignidad de la persona, respecto a su integridad moral y protección de la infancia» y «la filiación cuyo acceso al Registro Civil se pretende es frontalmente contraria a la prevista en el art. Io de la Ley de Técnicas de Reproducción Humana Asistida y, como tal, incompatible con el orden público, lo que impide el reconocimiento de la decisión registral extranjera en lo que respecta a la filiación que en ella se determina». En segundo lugar, afirma que no hay discriminación por razón de sexo u orientación sexual por el hecho de que sí sea posible inscribir la filiación a favor de dos mujeres si una de ellas se somete a las técnicas de reproducción asistida, porque se trata de supuestos diferentes. En tercer y último lugar, el TS analiza el interés superior del menor que entienden los recurrentes vulnerado y entiende que la aplicación del interés superior del menor «ha de hacerse para interpretar y aplicar la ley y colmar sus lagunas, pero no para contrariar lo expresamente previsto en la misma» además de que deben de tomarse más principios en consideración y no solo el interés superior del menor y, en último término, insta al Ministerio Fiscal a que ejercite las acciones pertinentes para determinar la filiación de los menores y para su protección.

Tras esta sentencia de 6 de febrero de 2014 los recurrentes instaron un incidente de nulidad de actuaciones al amparo del art. 24I de la Ley Orgánica 6/1985, de I de julio, del Poder Judicial por entender que se habían vulnerado sus derechos fundamentales a la tutela judicial efectiva, a la igualdad y a la intimidad familiar. En el lapso de tiempo transcurrido entre la presentación del incidente de nulidad de actuaciones y el día señalado para que el TS lo resolviera, el TEDH había resuelto por Sentencias del 26 de junio de 2014 los casos Mennesson c. France (Asunto núm. 65I92/II) y Labassee c. France (Asunto núm. 6594I/II) también relativos a la negativa de Francia a inscribir en su Registro Civil a las nacidas mediando gestación por sustitución acordada en este caso por parejas heterosexuales y en los cuales el TEDH declaró que la negativa del Estado francés a reconocer el vínculo de filiación entre las menores y las parejas comitentes es contraria al derecho de las primeras al respeto por su vida privada, protegida por el artículo $8 \mathrm{CEDH}$ y vinculada con la identidad $^{66}$. Como decía, estas sentencias del TEDH salieron a la luz antes de que el TS resolviera mediante Auto de 2 de febrero de 2015 el incidente de nulidad de actuaciones por lo que las tuvieron en cuenta a la hora de resolverlo, permitiendo también a las partes alegar lo que considerasen oportuno en relación con los pronunciamientos de esas sentencias. No

\footnotetext{
${ }^{66}$ FARNÓS AMORÓS, E., «La filiación derivada de...», cit., págs. 46 y 47.
} 
obstante el TS apeló, entre otros argumentos, a la falta de correspondencia entre el objeto del pronunciamiento español y los del TEDH para negar la declaración de nulidad de la STS de 6 de febrero de 2014 ya que en el caso resuelto por aquél las autoridades francesas no permitían la determinación de la filiación ni por adopción ni por vía judicial mientras que el TS si atendió a la posibilidad de determinación de la filiación paterna a favor del padre biológico.

Por tanto, visto lo anterior, el statu quo viene dado, por un lado, por lo sentado jurisprudencialmente tras la STS de 6 de febrero de 20I4, que niega la inscripción de nacimiento y filiación de los menores nacidos por gestación por sustitución en el extranjero mediante la aportación de una certificado de nacimiento expedido por las autoridades registrales extranjeras y, por otro lado, en la Instrucción de la DGRN de 5 de octubre de 20IO que regula los criterios de acceso al Registro Civil español de los nacidos en el extranjero mediante la gestación por sustitución que, recuerdo, exigía una resolución judicial del Estado extranjero que determine la filiación del nacido y negaba la certificación registral extranjera como título apto para inscribir el nacimiento y la filiación. En este sentido, la DGRN emitió con fecha II de julio de 2014 una Circular en la que disponía que la Instrucción de 5 de octubre de 20 Io estaba plenamente vigente y debía seguir siendo aplicada por los Registros Civiles españoles sin que la STS de 6 de febrero de 20I4 constituyera un obstáculo legal para ello.

\section{IV.4. Determinación judicial: acciones de filiación}

Una vez vista la determinación extrajudicial de la filiación derivada del uso de técnicas de reproducción asistida resta por ver la determinación judicial, lo que nos lleva a hablar de las acciones de filiación.

Las acciones de filiación según RIVERO HERNÁNDEZ son «aquéllas que tienen por objeto obtener de los órganos jurisdiccionales un pronunciamiento relativo a la filiación, ya declarándola si no ha quedado determinada de otra manera, o bien negando que lo sea la establecida formalmente» ${ }^{67}$. El Código civil distingue así entre las acciones de reclamación, cuya pretensión es determinar judicialmente la filiación y en las que diferencia entre si media o no posesión de estado para atribuir la legitimación; y las acciones de impugnación, dirigidas a dejar sin efecto una filiación que ha sido previamente determinada, y dentro de las cuales puede diferenciarse entre aquellas cuya pretensión es impugnar una filiación que no es conforme con la verdad biológica y aquellas cuya pretensión es impugnar el reconocimiento de una filiación por estar éste afectado por vicios del consentimiento.

Por su parte, la LTRHA no regula en su articulado un régimen de acciones específico por lo que ex art.7.I LTRHA habrá que estar al sistema de acciones previsto en el Código civil, a salvo de las contadas reglas concretas que se contienen en la LTRHA. Esto es así a pesar de que en la filiación derivada de técnicas de reproducción asistida prevalece la

\footnotetext{
${ }^{67}$ Martínez De Aguirre Aldaz, C., «Capítulo I4...», cit., pág. 33I.
} 
voluntad, el consentimiento, frente a la verdad biológica ${ }^{68}$, por lo que, en principio, el sistema de acciones previsto en el Código civil, que pretende hacer coincidir la filiación jurídica con la biológica, no se articula bien cuando se trata de filiación por técnicas de reproducción asistida. En este apartado trataré de poner de manifiesto los supuestos de inimpugnabilidad y reclamación a que se refiere la LTRHA así como los que generan más controversia por la remisión al Código civil y el difícil encaje de sus reglas con la voluntad preeminente de la LTRHA, así como las lagunas en que incurre la LTRHA y la posibilidad de aplicación analógica de algunas reglas a supuestos no contemplados en ella. Para ello diferenciaré entre los supuestos de fecundación heteróloga, a los que la LTRHA ha prestado más atención, y los de fecundación homóloga, que obligan a remitirse a las acciones de filiación del Código civil.

\section{IV.4.I. Acciones de filiación en caso de fecundación heteróloga}

La LTRHA en su art. 8.I recoge la regla en virtud de la cual se prohíbe a la mujer progenitora y al marido la impugnación de la filiación derivada de la fecundación asistida con contribución de donante cuando hayan prestado su consentimiento formal, previo y expreso a la fecundación. Este precepto no hace mención a la imposibilidad del hijo de impugnar la paternidad por lo que parte de la doctrina coincide en entender que el hijo estará legitimado para hacerlo en virtud del art. $137 \mathrm{Cc}^{69}$ y otra parte entiende que si se analiza la cuestión desde los principios que subyacen en la LTRHA lo lógico sería permitir la impugnación del hijo solo si el marido no ha prestado su consentimiento a la reproducción asistida ${ }^{70}$. Lo que no podrá hacer el hijo es reclamar la paternidad del progenitor biológico ya que éste, que será quien haya donado su semen, está protegido por el anonimato del donante y no podrá determinarse la filiación a su favor ex art. 8.3 LTRHA.

Al hilo de la regla de inimpugnabilidad de la filiación por parte de la mujer progenitora y el marido que han consentido a la reproducción asistida con contribución de donante surge la duda de qué solución tendría el marido que no ha prestado su consentimiento y, sin embargo, por aplicación de la presunción de paternidad se le atribuye la paternidad del nacido. Faltando el consentimiento o habiéndose prestado con vicios, debería permitirse impugnar la filiación si se sigue la intención de la LTRHA de dar tanta importancia al consentimiento para determinar la filiación ${ }^{75}$.

En cuanto al art. 8.2 LTRHA, sobre fecundación heteróloga en caso de pareja no casada, solo se hace mención en él a la posibilidad de reclamar judicialmente la paternidad, pero no aclara quién tiene la legitimación activa. La doctrina ha reflexionado y ha dicho que no tiene sentido que sea el donante de semen el legitimado para reclamar la paternidad

\footnotetext{
${ }^{68}$ BARBER CÁRCAMO: «En la reproducción asistida se ha sustituido el dato biológico por el consentimiento para la práctica de tales técnicas, pero el legislador no ha abordado la regulación de un sistema de acciones concorde con dicho planteamiento», La filiación en España..., cit., pág. 237.

${ }^{69}$ Vid., entre otros, Martínez De Aguirre Aldaz, C., «Capítulo i4...», cit., pág. 347; Barber CÁrCAmo, R., «Reproducción asistida y...», cit., pág. 35 .

${ }^{70}$ Opina de este modo Verdera Server, R., «Comentario a los...», cit., pág. 278.

${ }^{71}$ PÉRez Monge, M., La filiación derivada..., cit., págs. 147 y I 57.
} 
dada la regla contenida en el art.8.3 LTRHA, por lo que los legitimados activamente serán la madre, el varón no casado que ha consentido la fecundación y el hijo con fundamento en la falta de éxito en la determinación extrajudicial o en el no reconocimiento por parte del varón del hijo nacido mediante estas técnicas. De igual modo, y siguiendo la regla de la no determinación de la filiación a favor del donante ex art. 8.3 LTRHA y los principios de la LTRHA, la pretensión debería dirigirse a reclamar la paternidad de quien ha prestado el consentimiento y no a poner de manifiesto la verdad biológica.

Por otro lado, no se recoge en el art. 8.2 LTRHA, a diferencia del art. 8.I, la prohibición de impugnar por parte de quien ha prestado el consentimiento. En este punto habrá de aplicarse analógicamente el art. 8.I, imposibilitando también la impugnación del varón no casado que consintión ${ }^{2}$. Dado que el consentimiento prestado por el varón no casado a la fecundación con contribución de donante de su pareja no supone la determinación inmediata de la filiación, sino que, como hemos visto, deberá acudir a los títulos de determinación extrajudicial contenidos en el art. I20 Cc, al contrario que en el supuesto de pareja casada, el hecho de que el varón no casado no haya prestado su consentimiento a la fecundación no supone abrir la vía para impugnar la filiación, pues ésta ni siquiera se habrá determinado si el varón no vuelve a prestar su consentimiento a la determinación no matrimonial.

Mayores problemas plantea el ejercicio de las acciones de filiación en el supuesto de la doble maternidad. La LTRHA no contiene ninguna mención al respecto y se discute la aplicación de las acciones de reclamación e impugnación del Código civil, basadas en el principio de verdad biológica, a un supuesto en el que la filiación se determina por la voluntad. En este caso, parte de la doctrina entiende que, con respecto a la impugnación, podrá ejercitarse tanto por la madre como por el hijo, pero con matices ${ }^{73}$; y otra parte afirma que no cabe la impugnación pues entiende aplicable analógicamente el art. 8.I LTRHA $^{74}$. Con respecto a la acción de reclamación de la filiación, la doctrina parece estar de acuerdo en negar la posibilidad de reclamar la filiación en el supuesto de doble maternidad ${ }^{75}$, siendo posible solo ejercitar la acción de reclamación cuya pretensión sea poner de manifiesto la existencia de un título de determinación. No obstante el TS ha venido reconociendo legitimación para ejercitar la acción de reclamación a la cónyuge de la madre biológica con base en el art. I3I Cc por mediar posesión de estado cuando no se había determinado la filiación por vía del art. 7.3 LTRHA $^{76}$.

\footnotetext{
72 BARber CÁRCAMO, R., «Reproducción asistida y...», cit., pág. 32.

${ }^{73}$ Entre ellos, Martínez De Aguirre Aldaz que afirma que podrá ser impugnada tanto por el hijo como por la madre biológica pero ésta en interés de aquél, «Capítulo I4...», cit., pág. 348; BARBER CÁRCAMO sostiene la legitimación del hijo para impugnar la filiación y la de la madre pero, en este caso, solo por defectos del título y reconduciéndola a la acción de rectificación registral del art. II4 Cc o también por vicios del consentimiento, reconduciéndola al art. I38 Cc, «Doble maternidad legal...», cit., págs. I22-I24; GonZÁLES PÉREZ DE CASTRO también afirma la posibilidad de impugnación de la cónyuge pero solo del reconocimiento por vicio del consentimiento, y la del hijo, La verdad biológica..., cit., pág.305.

${ }^{74}$ DíAz MARTíneZ, A., «La doble maternidad...», cit., pág.88.

${ }^{75}$ Vid. BARBER CÁRCAMO, R., «Doble maternidad legal...», cit., pág. I20 nota 5I.

${ }^{76}$ Vid. STS 740/2013, de 5 de diciembre y STS 836/2013, de I5 de enero.
} 
IV.4.2. Acciones de filiación en caso de fecundación homóloga

En caso de fecundación homóloga mediando matrimonio o no, la LTRHA no contempla ninguna regla específica por lo que habrán de aplicarse las acciones contenidas en el Código civil. Así, cobra importancia en este punto el consentimiento prestado (o no) a la reproducción asistida de la mujer. En este sentido, puede darse el caso de que el hijo nazca por aplicación de técnicas de reproducción asistida con el semen del marido pero sin el consentimiento de éste y al cual se le atribuirá la filiación por la presunción de paternidad del art. iı6 Cc. Si el marido desea impugnar la paternidad se encontrará con el problema de que va a impugnar una paternidad jurídica que coincide con la biológica por lo que su pretensión quedará vacía de contenido dada la finalidad de las acciones de impugnación de la filiación en el Código civil pero, por otro lado, en virtud de la prevalencia que la LTRHA da al consentimiento, sería lógico que se estimara su acción de impugnación de filiación basada en la falta de consentimiento ${ }^{77}$.

$\mathrm{Si}$, por el contrario, el marido sí ha prestado su consentimiento a las técnicas de reproducción asistida y se le ha atribuido la filiación en virtud de la presunción de paternidad podría aplicarse por analogía el art. 8.I LTRHA que, como hemos visto, impide impugnar la filiación matrimonial del hijo nacido como consecuencia de la fecundación con semen de donante, de modo que no se permitiera igualmente al marido o varón no casado que ha prestado su material genético impugnar la paternidad. No es unánime la doctrina en este sentido, habiendo quien entiende que estamos ante supuestos distintos y por tanto no procede la analogía.

En cuanto a la reclamación de la filiación, puede darse el supuesto de que hayan transcurrido trescientos días desde la separación de los cónyuges y el marido, habiendo consentido al uso de las técnicas de reproducción asistida de su mujer con su material genético, no preste el consentimiento requerido ex art. iı8 Cc para inscribir al hijo como matrimonial, en cuyo caso deberá declararse su paternidad ejercitando una acción de reclamación de paternidad en virtud de los arts. I3I y I32 dependiendo de si media o no posesión de estado. Sin embargo, si el marido no ha consentido la fecundación de la mujer ni tampoco prestó el consentimiento en virtud del art. Iı8 Cc, dando prevalencia al elemento volitivo y restándosela al biológico (pues el marido es padre biológico del así nacido), no podrá declararse su paternidad ejercitando la acción de reclamación de filiación ${ }^{78}$.

\footnotetext{
${ }^{77}$ Así lo entiende Verdera Server que en relación con este supuesto dice lo siguiente: «La aplicación de las reglas del Código civil sobre impugnación conduciría a la desestimación de la pretensión, pero entendemos que esas reglas se deben acomodar a las peculiares características de la filiación derivada de técnicas de reproducción asistida, en la que reviste un peso fundamental el consentimiento de los interesados. Por ello, consideramos que la impugnación basada en la falta de consentimiento del marido debe estimarse, a pesar de que genéticamente ese hijo provenga del marido de la madre», «Comentario a los...», cit., pág. 277 y 278. Opina de manera contraria PÉREZ Monge, que entiende que el marido deberá ser calificado como padre del nacido a pesar de que en la LTRHA el consentimiento sea un elemento clave en la determinación de la filiación. Y esto debido a que, entre otras razones, al no prever la LTRHA el supuesto, la aplicación de las reglas del Código civil ex art. 7.I llevarían a considerar al marido que aporta el gameto como padre del nacido, «Filiación derivada del empleo de las técnicas de reproducción asistida» en Monje BalmasedA, O. (coord.), Los 25 temas más frecuentes en la vida práctica del Derecho de Familia, Tomo I (Parte sustantiva), Dykinson, Madrid, 20II, pág. 587.
}

${ }^{78}$ Verdera SERVER, R., «Comentario a los...», cit., págs. 274 y 275. 
En caso de que no medie matrimonio, el varón no casado que, habiendo prestado el consentimiento, no ha determinado extrajudicialmente su paternidad también podrá ejercitar la acción de reclamación de paternidad y también estarán legitimados el hijo y la madre ${ }^{79}$. Podrá igualmente impugnar la paternidad conforme al art. I4I Cc si ha mediado error, violencia o intimidación en la determinación extrajudicial.

Por último, si estamos ante procreación post mortem en pareja no casada, el art. 9.3 prevé la posibilidad de que se ejercite la acción judicial de reclamación de paternidad, que podrá ejercitar el hijo (art. I33 Cc).

Para concluir, resta por añadir que el art. I0.3 LTRHA permite, en caso de gestación por sustitución, que el padre biológico, es decir, aquél que aporta el material genético (pero no el donante dado el anonimato del mismo) pueda ejercitar la acción de reclamación de la paternidad.

\section{Conclusiones}

La filiación derivada de técnicas de reproducción asistida no se regula en el Código civil sino que tiene un régimen específico contenido en la LTRHA que se concreta en una serie de reglas especiales. Para todo lo no regulado en ella, la propia LTRHA en su art. 7.I se remite al régimen del Código civil.

La insuficiencia de estas reglas especiales a menudo obliga a acudir a la regulación que de la filiación por naturaleza hace el Código civil, pero el fundamento de una y otra en orden a la determinación de la filiación difiere: en la filiación por naturaleza se considera formalmente padre a quien lo es biológicamente mientras que en la derivada de técnicas de reproducción asistida se determina por la voluntad de quien consiente, que puede no ser quien aporta su material biológico.

Como corolario de lo anterior, la determinación de la filiación derivada de reproducción asistida homóloga no plantea mayores inconvenientes dado el paralelismo con la filiación por naturaleza, sin embargo no ocurre lo mismo en caso de reproducción asistida heteróloga, donde se sustituye el elemento biológico por el volitivo, no permitiendo determinar la filiación a favor del donante y verdadero padre biológico, pero sí a favor de quien da su consentimiento pero no aporta su material genético. En ambos casos, no obstante, la filiación se determina, no por el consentimiento dado, sino a través de los títulos de determinación contenidos en el Código civil en función de si estamos ante filiación matrimonial o no matrimonial; con la excepción de la doble maternidad donde el simple consentimiento determina la filiación.

La problemática es similar con respecto a la determinación judicial ya que, a salvo de las contadas reglas, la LTRHA no incluye un régimen de acciones de filiación específico por lo que es preciso aplicar el del Código civil. Este modo de proceder lleva a problemas de

\footnotetext{
${ }^{79}$ La SAP de Alicante, de 23 de diciembre de 2014 estima la reclamación de paternidad extramatrimonial presentada por la madre contra el hombre que había aportado su semen y había consentido a que fuera inseminada con él y que manifestaba que una donación de semen no debe significar la atribución de una paternidad.
} 
aplicación dados los distintos principios que inspiran ambas regulaciones: el régimen de acciones del Código civil está dirigido a poner de manifiesto la verdad biológica para, una vez conocida, determinar la filiación o destruir la ya determinada por no corresponderse con la realidad biológica; mientras que en la LTRHA la impugnación o reclamación de una filiación no tiene siempre como pretensión adecuar la filiación a la verdad biológica, sobre todo en fecundación heteróloga. Así, atendiendo a la importancia que la LTRHA da al consentimiento prestado a la reproducción asistida, es este consentimiento o la ausencia del mismo el que cierra o abre la puerta a posibles impugnaciones y reclamaciones de la filiación. Por eso en ocasiones se reclamará la paternidad de quien en realidad no es padre biológico pero ha dado su consentimiento o se permitirá impugnar la paternidad a quien es padre biológico pero no ha prestado el consentimiento.

Todo ello obliga a preguntarse acerca de la posibilidad de incluir en el Código civil un nuevo tipo de filiación: la filiación derivada de técnicas de reproducción asistida, con un régimen específico que gire en torno a la voluntad y que exima de aplicar reglas pensadas para la filiación por naturaleza y que, como ha quedado expuesto a lo largo del artículo, solo conducen a contradicciones. 